\title{
Drivers of Employee Engagement in Global Virtual Teams
}

\section{Farheen Fathima Shaik}

Indian Institute of Management

Tiruchirappalli

farheen.f16006@iimtrichy.ac.in

\section{Upam Pushpak Makhecha}

Indian Institute of Management

Tiruchirappalli

\section{Abstract}

Global Virtual Teams (GVTs) comprise geographically distributed groups of people collaborating with each other through technology-mediated communication. Members of GVTs are from different cultural backgrounds and time zones, who may (or may not) meet in person to take complex decisions or to deliver on the tasks that are of strategic importance. Though technology has enabled GVTs in almost all multinational organisations across all industries, keeping the members of GVTs engaged over the duration of the team's task or project could still pose a challenge for organisations. Employee engagement is defined as an employee's cognitive, behavioural and physical state directed towards organisational outcomes. While employee engagement has been researched in a collocated team context, it remains an under-researched area in the context of GVTs. Given that there are several characteristics of GVTs which are distinct from the collocated team, it warrants a separate inquiry, which we undertake in this study. This study uses the Job Demands-Resources theory of employee engagement to derive the drivers of employee engagement in GVTs. Through interpretive analysis of the lived experiences of members working in an organisation which extensively uses GVTs for achieving its strategic goals, we conceptualise five drivers of employee engagement, namely, cultural intelligence, communication (formal and informal), technology, trust and individual maturity.

Keywords: Employee Engagement; Geographically Dispersed Teams; Global Virtual Teams; Phenomenology; Technology Mediated Communication.

\section{Introduction}

Technological developments and global mobility have resulted in expansion of the scope of teams beyond the traditional collocated forms (Matlay \& Martin, 2009) towards geographically dispersed and global forms of teams working virtually and connected through technology, commonly known as the Global Virtual Teams (GVTs) (Jiminez, Boehe, Taras, \& Caprar, 2017). These types of teams are also known as "multinational and multicultural distributed teams" (Connaughton \& Shuffler, 2007) or "transnational teams" (Haas, 2006). GVTs, as a form of organising work through technology-mediated communication and through a workforce spread across cultures and boundaries, has become a norm for all types and forms of organisations rather than being limited to large firms. Such teams include not only full-time employees but also part-time employees, freelancers, suppliers and other forms of collaborations (Jiminez et al., 2017). Such teams require an appropriate choice of technology for interaction among team members for effective communication via technology (Morgan, Paucar-Caceres, \& Wright, 2014). 
Due to the increase in virtual forms of work mediated through technology, and multicultural nature of workforce that is becoming ubiquitous and indigenous to all types of firms, it is prudent for researchers and practitioners to explore and understand the challenges of working in GVTs. Dulebohn and Hoch (2017) report the challenges faced by members of GVTs as 1) understanding speech patterns in multicultural GVTs; 2) leading efficiently; 3) combining and collaborating with different time zones; 4) developing personal rapport; 5) being on technology-mediated communication; and 6) selecting appropriate communication channels. These challenges are known to have a negative impact on results, including productivity, costs, deadlines, and retention as well as morale and stress of the employees (Grenny \& Maxfield, 2017; Tran, Yang, \& Raikundalia, 2004). In general, one of the measure used by organizations to counter some of these negative impacts is to focus on increasing employee engagement levels (Gilson, Maynard, Young, Vartiainen, \& Hakonen, 2015). Higher levels of employee engagement in organizations have been reported to increase the financial performance and employee productivity (Harter et al, 2002). Observations by consulting firms like Aon, Gallup, also suggest that employee engagement drives organizational results. Especially Aon Hewitt (2005) emphasizes that they "have established conclusive, compelling relationship between engagement and profitability through higher productivity, sales, customer satisfaction, and employee retention". However, it is alarming to note that the engagement levels are found to be lower in GVTs. Practitioner report such as KPMG (2012) specifies that though "costconscious businesses are turning to technology to become increasingly flexible and virtual....employee engagement measures from GVTs are lower than those for on-site teams that work close to each other" (pg. 4). Though the practitioner literature reports reduced levels of employee engagement in GVTs, there is scant scholarly work on employee engagement in GVTs. Thus, in our view, due to the changed context of working in GVTs which is characterised by virtuality, technology-mediated communication and multicultural interaction, and the ubiquitous presence of GVTs in organisations, it is critical to understand the phenomenon of employee engagement in GVTs through scholarly research and identify factors that can influence engagement of team members of GVTs.

This study is an interpretative analysis of employee engagement in GVTs. As employee engagement in virtual teams is an underexplored area (Gilson et al., 2015), as a starting point this research has used phenomenology as its methodological approach to understand employee engagement from the narratives and lived experiences of team members of GVTs. From this interpretative analysis, we conceptualise the drivers of employee engagement that emerge from our study and compare these with antecedents of employee engagement researched in collocated teams as per extant literature. In a nutshell, this study tries to answer the question, "What drives employee engagement in the context of GVTs?"

In following sections, we first provide a brief overview of the challenges teams face in a virtual context. We then highlight the importance of employee engagement in organisations and theories used to explain employee engagement, with specific focus on Job Demands-Resources (JD-R) theory, which we use in this study to understand employee engagement in GVTs. This section also highlights reasons for the authors to anticipate change in drivers of employee engagement in GVTs as compared to collocated teams. The third section of this paper discusses the relevance of phenomenology as a methodology in deriving the drivers of employee engagement in GVTs. We then move on to describe evolved themes and their interpretations, followed by a discussion and end with a conclusion. 


\section{Virtuality and Teams}

Due to rapid changes in environment such as digitization, globalisation, and increased complexity, organisations today have turned towards team-based work structures in order to respond quickly to the dynamic environment to stay competitive. At the same time, with technology, communication, and competition, it has become necessary for organisations to unite globally distributed units with differences in culture and skill-sets. This has made information and communication technologies inevitable for a team to subside the spatial and temporal barriers, and meet the demands of work (Alnuaimi, Robert, \& Maruping, 2010), making GVTs a preferred choice for managing work. GVTs have been earlier defined by Henry and Hartzler (1998) as "groups of people who work closely together even though they are geographically separated by miles or even continents" (pg. 5) and later by Powell, Piccoli, and Ives (2004) as "a group of geographically, organisationally and/or time dispersed workers brought together by information technologies to accomplish one or more organisation tasks" (pg. 7) to capture the temporary nature of GVTs and the critical role of communication technologies across GVT members. The concept of virtual implies permeable interfaces and boundaries; teams that rapidly form, reorganise and dissolve when the needs of dynamic marketplace change; and individuals with differing competencies located across different time, space and cultures (Bell \& Kozlowski, 2002). These teams also address new workforce demographics where the best employees may be located anywhere in the world and where workers increasingly are demanding technological sophistication and personal flexibility (Burn \& Robins, 2002; Townsend, DeMarie, \& Hendrickson, 1998).

The main assumption behind formation of such teams is that people will contribute as much in GVT settings, as they do in a collocated team (Alnuaimi, Robert, \& Maruping, 2010). However, as per existing literature, members of GVTs face certain challenges and this is reflected in low individual commitment; role overload; role ambiguity; absenteeism and social loafing; communication and collaboration difficulties; potentially lower team engagement by team members; difficulty in creating and maintaining trust; high levels of social and psychological isolation between members; and challenges in managing and monitoring teams (Dulebohn \& Hoch, 2017; Johansen, 1994; Matley \& Martin, 2009). Further, as organisations implement new technologies into team-based structures, researchers began to identify hurdles that these teams may need to overcome (Dulebohn \& Hoch, 2017; Schaubroeck \& Yu, 2016) such as limitations in team identification (Raghuram \& Wiesenfeld, 2004); managing diversity (Gibson \& Gibbs, 2006); and determining leadership in GVTs (Bell \& Kozlowski, 2002; Hoch \& Kozlowski, 2014). Addressing and keeping such challenges in check has the potential to enable the advantages of working in a virtual environment (Burgess, Kerr, \& Houghton, 2013).

In a global virtual context, a team assumes that its members set interdependencies and a common purpose that is unique to the team. The individual efforts are pooled and the need for interacting directly is limited. Therefore, the quality of communication in a team becomes important, particularly in case of distributed teams compared to those that are not (Morgan, Paucar-Caceres, \& Wright, 2014; Schaubroeck \& Yu, 2016). In our view, the virtual context of working in GVTs with dispersion of employees over multiple geographic locations, coupled with complete reliance on technology for communication and other such factors could potentially reduce the levels of employee engagement, as also reported by practitioner organisations (Aon-Hewitt, 2013; KPMG, 2012) Therefore, in this study, we contend that as the challenges faced by members working in GVTs are different when compared to a collocated 
team, we propose that dynamics of employee engagement in GVTs might be different from those of collocated teams. The next section discusses employee engagement and its antecedents in the context of collocated teams, and also argues that existing antecedents might not completely predict employee engagement in a virtual, technology-mediated and multicultural context.

\section{Employee Engagement}

The existing literature acknowledges that employee engagement is key to organisational success and competitive advantage (Macey, Schneider, Barbera, \& Young, 2009; Rich, LePine, \& Crawford, 2010; Saks \& Gruman, 2014). Also, it is one among the very few constructs which have captured the attention of academicians and practitioners alike (Saks \& Gruman, 2014). According to Kahn (1990), when employees are engaged, they bring cognitive, emotional and behavioural aspects of themselves at work towards performance, thus displaying their complete selves within their job roles (Saks \& Gruman, 2014). And when employees are disengaged they decouple themselves from their work roles, and withdraw themselves cognitively, emotionally and physically during role performances (Kahn, 1990, pg. 694). According to Maslach, Schaufeli, and Leiter (2001) employee engagement involves vigour, dedication and absorption of employees in their jobs and is seen as an antithesis of burnout dimensions of exhaustion, cynicism, and inefficacy. Recently, Shuck and Wollard (2010), define employee engagement as "an individual employee's cognitive, emotional, and behavioural state directed toward desired organisational outcomes" (pg. 103). This definition conceptualises the three dimensions given by Kahn (1990) and also relates them to organisational performance and hence we take this definition of employee engagement for this paper.

The extant literature uses several models and theories to explain employee engagement. Three major theories being- the theory of psychological meaningfulness by Kahn (1990), engagement as a positive antithesis of burnout (Maslach et al., 2001) and the Job Demands-Resources (JDR) model by Bakker and Demerouti (2007) (Saks \& Gruman, 2014). The first theory of employee engagement by Kahn (1990) found that employee engagement was a function of experiencing three psychological conditions, namely, psychological meaningfulness, psychological safety, and psychological availability. Those employees who experience higher levels of psychological meaningfulness (being valuable, useful and worthwhile); psychological safety (being able to express one's true self without the fear of negative consequences to one's selfimage, status or career) and availability have been reported to engage more in their roles (Saks \& Gruman, 2014). Those social systems that are predictable, consistent and non-threatening provide higher levels of psychological safety (Kahn, 1990). In the context of GVTs, we question the sense of psychological safety due to the interactions among team members that are predominantly mediated through a technological medium. The expression of self through various forms of technology might differ in comparison to a collocated team where the emphasis is on face to face (FtF) communication (Morgan et al., 2014). In context of GVTs we anticipate that this can lead to either a reduced or alleviated form of psychological meaningfulness of work. Psychological availability is when an employee is present psychologically, emotionally, and physically in their work, leading to higher levels of engagement. Considering the contextual difference in GVTs, the authors assume that expression of availability might also differ considerably in comparison to a collocated team. 
The second theory of engagement is based on burnout literature. Maslach et al. (2001) discuss that engagement is the antithesis of burnout. According to them, burnout is an outcome of mismatch of six critical areas of organisational life, which are also reported to be antecedents of burnout: workload, control, rewards and recognition, community and social support, perceived fairness, and values. The greater alignment of these areas will lead to improved employee engagement, and it includes sustainable workload, feelings of choice and control, appropriate recognition and reward, supportive work community, fairness and justice, and meaningful and valued work (Maslach \& Leiter, 2008). Considering the context of GVTs, the authors contend that among the six factors identified by Maslach et al. (2001), contextual factors like perceived fairness, values, community and social support, and control in GVTs might take newer meanings for the team members. Changes in these factors may help us understand the ways in which employees feel engaged in a geographically dispersed and technologically mediated team. Limiting factors of GVTs like lack of FtF interactions, extensive geographic dispersion makes us assume that levels of engagement might differ across multiple forms of communication.

Job Demands-Resources (JD-R) theory is an extension of the burnout theory in which Bakker and Demerouti (2007) emphasise on working conditions to improve employee engagement. This was first used to explain burnout as a consequence of two processes- one, high job demands which leads to exhaustion; and two, lack of job resources which leads to withdrawal of employees. These two broad categories of job demands and job resources have been used to explain employee engagement as well. Proposed originally by Demerouti, Bakker, Nachreiner, and Schaufeli (2001), the JD-R model describes how job demands and resources trigger motivational and psychological health impairment processes. Meta-analytic evidence shows that motivational processes through job resources such as autonomy, task variety, feedback, training and development, participation in decision-making, co-worker support, and supervisor support are positively related to employee engagement (Crawford, LePine, \& Rich, 2010; Halbesleben, 2010). There is also meta-analytic evidence which states that job demands such as work overload, role conflict and ambiguity, emotional demands, can adversely impact employee health, wellbeing and performance (Albrecht \& Anglim, 2018; Alarcon, 2011).

We anticipate that job resources such as feedback, participation in decision making, co-worker support, and supervisor support could be different in GVTs in comparison to a collocated teams. Also, changes in job demands, especially emotional demands due to contextual differences of GVTs can trigger changes in engagement level in GVTs. This paper relies on the JD-R model as it focuses on the contextual factors of GVTs that predict engagement and disengagement of employees rather than psychological factors as in other theoretical approaches. The change in context of GVTs and the limitations that team members of GVTs face can affect the drivers of their engagement. Therefore, this study tries to answer the question, "What drives employee engagement in GVTs?"

\section{Methodology}

In this study, we use phenomenology, a form of qualitative inquiry which is a philosophy (Heidegger, 1962; Husserl, 1962) and a methodology (Schutz, 1967) which incorporates details of experiences in everyday life at a rather mundane level. In our view, phenomenological inquiry best suited the context of this study as we wanted to understand employee engagement in GVTs from the team members' perspective reflected in their experiences as it 
is an underexplored research area. The main goal of phenomenology is to critically reflect the conscious experience rather than subconscious motivation, by uncovering important and invariant features of those lived experiences of participants (Jopling, 1996) and, thus, there is "fidelity to the phenomena as it is lived" (Wilson, 2002). Phenomenology emphasises on "careful study of individuals to discover deeper meaning of 'lived' experiences in terms of the individual relationship with time, space and personal history" (Stern, 1994). The new context and lack of academic literature on employee engagement in GVTs necessitated the need to first understand the phenomena as is, from the narratives of lived experiences of team members, and make meaning of their stories towards developing convergences and divergences according to the phenomenological accounts.

In this study, interpretation of participants' reflection on employee engagement in GVTs emerged through a circular interplay between developing understanding of phenomenological interviews (Thompson, Locander, \& Pollio, 1989) and ongoing immersion in several key literatures relevant to participants' reflections, namely, (1) JD-R model of employee engagement; (2) literature on GVTs; (3) on multicultural implications; and, on (4) technology adaptation in organisations. The resulting interpretation seeks to articulate a theoretical interplay between drivers of employee engagement as articulated in academic literature, and phenomenological descriptions of meanings that events and experiences assume in life worlds of the members of GVTs.

The study was carried out at Cyient Ltd., a global organisation headquartered in Hyderabad, India, with a presence in 47 countries and employing about 14,000 employees. Cyient extensively uses GVTs due to its geographical presence in many countries. At the outset of this investigation, a list of potential participants was developed from Cyient Ltd. Purposive sampling criteria for phenomenological interviews (Thompson, 1996) were based on the degree of virtuality of the team, and the experience of working in GVTs. The degree of virtuality was based on three criteria as first given by O'Leary and Cummings (2007): (1) spatial, which is the geographic distance among team members; (2) temporal, which is the time difference among team members; and, (3) configurational, which is the locations where team members work alone or the uneven distribution of team members. These criteria provided a specific set of circumstances to situate the findings of this study and hence facilitate in-depth and localised accounts of the phenomena (Sherry, 1991).

The master data set of the employees was accessed to select teams based on the above selection criteria. Three teams (26 members) were selected accordingly (see Table 1). Team managers of these three teams were contacted for consent to contact their respective team members. Sixteen of the 26 members of the three GVTs selected responded positively towards the research. The teams were selected where respondents belonged to managerial positions. This purposive selection was done as these members have experienced virtual teams as managers as well as team members, and the questionnaire was designed accordingly. It was expected that their experience of working in a virtual team can be more holistic leading to richer data for research. Before the interviews, participants were assured of anonymity and they signed consent forms which explained the purpose and intended use of this investigation. 


\begin{tabular}{|c|c|c|c|c|c|c|c|c|c|}
\hline Team & Designation & Gender & $\begin{array}{l}\text { Service at } \\
\text { Cyient }\end{array}$ & Age & $\begin{array}{l}\text { Location } \\
\text { (Seating) }\end{array}$ & Country & Continent & $\begin{array}{l}\text { Interview } \\
\text { Duration }\end{array}$ & $\begin{array}{l}\text { Interview } \\
\text { Medium }\end{array}$ \\
\hline \multirow[t]{8}{*}{ Team A } & General Manager & Male & 15.2 & 43 & Hyderabad - Manikonda & India & Asia & 0:55:00 & Telephone \\
\hline & Vice President (Sales) & Male & 6 & 56 & London & UK & Europe & 0:57:00 & Telephone \\
\hline & Senior Sales Manager & Male & 4 & 48 & Kuala Lumpur & Malaysia & Southeast Asia & 0:45:00 & WebEx \\
\hline & Assistant General Manager & Male & 3 & 43 & Sydney & Australia & Australia & 0:43:00 & Telephone \\
\hline & Senior Project Manager & Male & 16.7 & 65 & Paragould & USA & North America & NR & NR \\
\hline & Senior Sales Manager & Male & 2.2 & 32 & Melbourne & Australia & Australia & NR & NR \\
\hline & Associate Vice President & Male & 14.4 & 52 & Dulles & USA & North America & NR & NR \\
\hline & Deputy General Manager & Male & 0.9 & 46 & Melbourne & Australia & Australia & NR & NR \\
\hline \multirow[t]{9}{*}{ Team B } & Associate Vice President & Male & 16.1 & 56 & Hyderabad - Madhapur & India & Asia & 0:45:00 & Face to Face \\
\hline & Assistant Manager & Female & 12.2 & 39 & Hyderabad - Manikonda & India & Asia & 1:03:00 & Face to Face \\
\hline & Associate Vice President & Male & 6.7 & 45 & East Hartford & USA & North America & 0:45:00 & Telephone \\
\hline & Senior Marketing Director & Female & 2.3 & 45 & London & UK & Europe & 0:55:00 & WebEx \\
\hline & Senior Project Manager & Male & 15.4 & 41 & Hyderabad - Madhapur & India & Asia & 0:40:00 & Face to Face \\
\hline & Sales Manager (Singapore) & Male & 1.1 & 53 & Seletar & Singapore & Southeast Asia & 0:37:00 & Telephone \\
\hline & Deputy General Manager & Male & 8.2 & 43 & Hyderabad - Manikonda & India & Asia & 1:10:00 & Face to Face \\
\hline & Senior Project Manager & Male & 6 & 43 & Bangalore & India & Asia & 1:05:00 & Face to Face \\
\hline & Senior Project Manager & Male & 6.5 & 55 & East Hartford & USA & North America & NR & NR \\
\hline \multirow[t]{6}{*}{ Team C } & Design Engineer & Male & 8.4 & 30 & Hyderabad - Manikonda & India & Asia & NR & NR \\
\hline & Design Engineer & Female & 7.6 & 31 & Hyderabad - Manikonda & India & Asia & 1:10:00 & Telephone \\
\hline & Design Engineer & Male & 6.3 & 31 & West Perth & Australia & Australia & 1:03:00 & Telephone \\
\hline & Design Engineer & Male & 8.4 & 29 & Peoria & USA & North America & NR & NR \\
\hline & Design Engineer & Male & 3.8 & 31 & Melbourne & Australia & Australia & NR & NR \\
\hline & Design Engineer & Male & 3 & 53 & West Perth & Australia & Australia & NR & NR \\
\hline Manager A & $\begin{array}{l}\text { Senior Vice President \& BU } \\
\text { Head }\end{array}$ & Male & 12 & 49 & Hyderabad - Madhapur & India & Asia & NR & NR \\
\hline Manager B & $\begin{array}{l}\text { Senior Vice President \& BU } \\
\text { Head }\end{array}$ & Male & 8.6 & 43 & Hyderabad - Madhapur & India & Asia & 0:37:00 & Face to Face \\
\hline Manager C & Senior Project Manager & Male & 3.7 & 41 & Hyderabad - Manikonda & India & Asia & 1:05:00 & Telephone \\
\hline
\end{tabular}

Table 1: Teams selected for phenomenological interviews (NR: Not Responded) 
As this research follows the tradition of qualitative inquiry we emphasised the development of highly in-depth analysis of life stories expressed by a small number of participants (Levy 1981; McCracken, 1988; Thompson, Locander, \& Pollio, 1990). The purpose of using a restricted sample was to gain an in-depth understanding of the experiences and also assumptions behind those experiences through which the participants construe their world (McCracken, 1988). This becomes an important rationale for the objectives of phenomenological research based on hermeneutics. The interviews occurred either FtF or through telephone or WebEx calling, based on the availability and comfort of participants and we followed the conventions of phenomenological interviewing as given by Thompson et al. (1989, 1990). Three pilot interviews were conducted by the researcher to fine tune the interview schedule. The interviews were conducted largely through dialogue set by the participants and followed up by questions based on experiences described by them. The interview dialogues ranged from 45 to 70 minutes. NVivo Pro 11 was used to transcribe audio tapes into text, leading to verbatim transcripts ranging from 15 to 25 single-spaced pages for each participant account. These transcripts of audio-taped interviews served as primary texts on which findings of this interpretative account is based. Apart from the transcripts, researchers had also taken notes while in the organisation which amounted to about 150 pages of everyday diary writing and constant observation.

Interpretation in phenomenological analysis is proceeded by means of hermeneutic logic (Thompson, Pollio, \& Locander, 1994). An iterative process of reading, documenting, and systematising interview transcripts (Thompson, 1996) was done. The transcripts were closely read to gain a sense of the whole and during this initial reading, the authors also started noting down key phrases, metaphors, and patterns of meanings. With every iteration, interpretation was developed and an effort towards getting a grasp of thematic similarities and meaningbased linkages was made. This process was undertaken for each participant and when the researcher felt that an internal structure is derived for a participant, attention was turned towards another and the process was repeated. An effort has also been made to note down similarities and differences from the interpreted interviews. As this iterative process continued, a larger pattern to capture essential dimensions through thematic relationships was derived. Throughout the process, we developed a thematic structure by continuously modifying, questioning, and returning to the experiences described by each participant in the interviews, as suggested by Thompson (1996). The iterative process was conducted using coding in NVivo Pro 11. There were 240 nodes identified in the first round of the coding process. Further, convergences led to the identification of 19 subordinate themes (Appendix II), from these themes nine emic interpretations were identified and finally these were mapped to five etic interpretations including: (1) cultural intelligence, (2) communication, (3) technology, (4) trust and (5) individual maturity. As Pike (1967) states "the etic viewpoint studies behaviour as from outside of a particular system and is an essential initial approach to an alien system, and the emic viewpoint results from studying behaviour as from inside the system" (pg. 37).

\section{A Hermeneutic Interpretation}

As a general overview, the interviews suggest that team members participating in this study had experience of working in GVTs since the start of their career, and they shared a common set of work settings and social circumstances. Further, awareness of belonging to GVTs seemed to be closely related to their perception that they, and other team members of the GVT, 
were working in a context which is very different from that of a collocated team. All members were aware of the context that they were working in, and the typified views of being part of GVTs. For example, throughout the interviews, participants spontaneously compared themselves to the working conditions and team members of a collocated team.

In presenting the following hermeneutic account, our goal is to retain the holistic quality that characterised the participants' descriptions while still providing analytic clarity. We first discuss the general structure of the thematic framework that emerged from hermeneutic analysis of interview transcripts. Figure 1 portrays the system of thematic relations emerging from interpretation of interview texts. The representation of data in Figure 1 follows the representation given by Thompson (1996). The vertical continuum ranges from 'experiencenear' to 'conceptually-abstract' (Thompson, 1996). This continuum suggests that concrete experiences and behaviours of participants manifest into higher order patterns of sociocultural meanings and processes.

\section{LEVELS OF ABSTRACTION IN THE INTERPRETATION OF TEAM} MEMBER EXPERIENCES OF EMPLOYEE ENGAGEMENT IN GVT'S

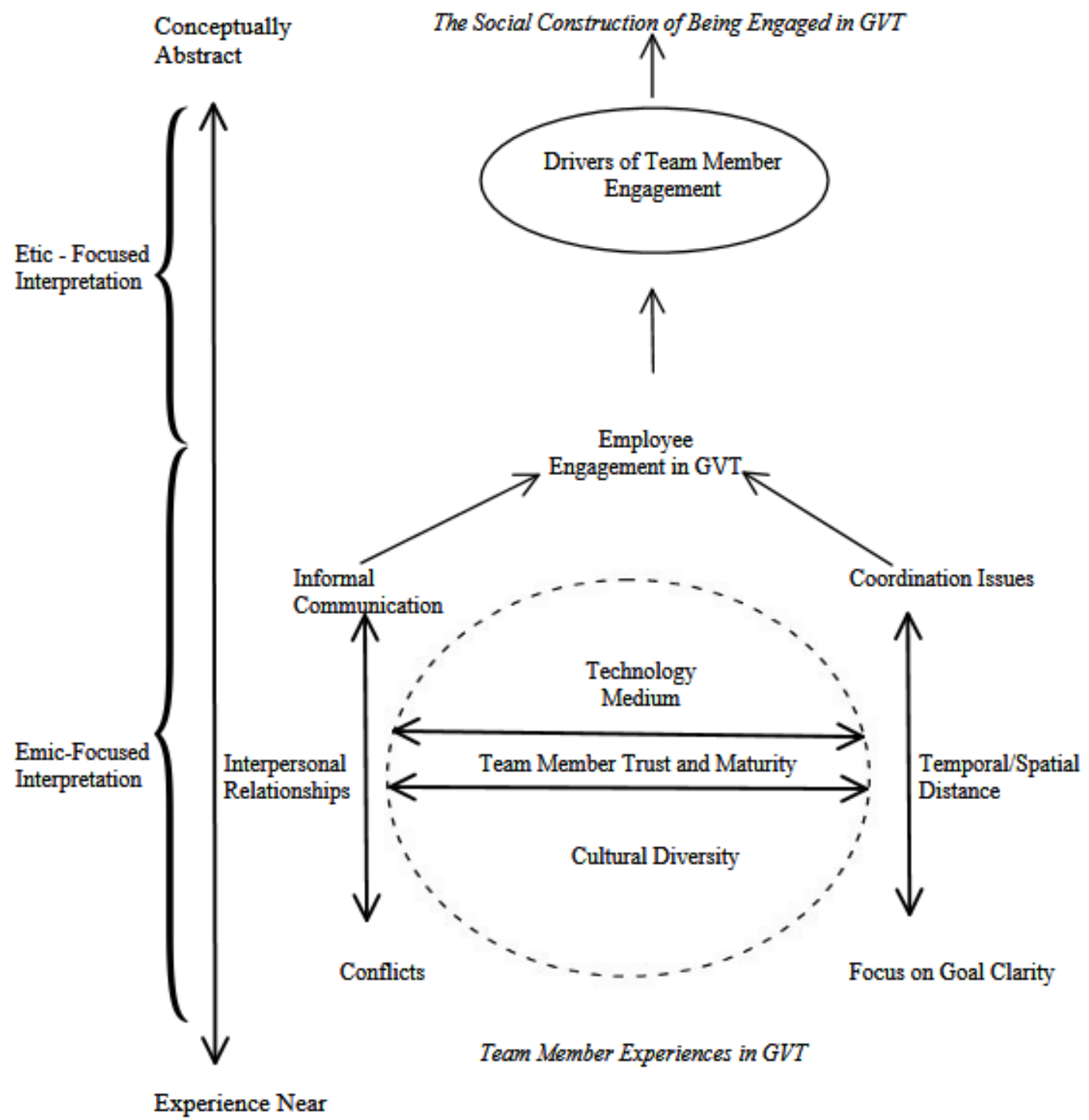

Figure 1: Levels of abstraction derived from phenomenological accounts of the participants, 
This continuum also represents interpretative movement from various levels of emic meanings to an etic framework that we use to situate the participants' perceptions in a broader system of sociocultural meanings.

The emic nomenclature has been derived from the vernacular of the participants. The levels of abstraction towards emic interpretations included, (1) participants' perceptions about a specific experience; (2) reflective meanings of those experiences; and (3) meanings that emerge by the interpretation of larger patterns across all interviews (Thompson, 1996). After presenting the emic account, an etic framework is conceptualised that links drivers of employee engagement in GVTs.

The placement of various themes of emic-focused interpretation (see Figure 1) was done based on relationships that emerged from the narratives of the respondents' lived experiences. It was found that GVT members faced challenges (demands) due to lack of goal clarity and coordination issues. And GVT members were trying to bridge these challenges by being sensitive to temporal and spatial distance among members and through constant communication for setting clear expectations on goals (resources). Similarly, the issues of conflicts and informal communication (demands) were being bridged by building adequate interpersonal relationships among the members of GVTs (resources) through various means. Also, context of GVTs implies that there is cultural diversity and extensive use of technology media for the team to be connected (demands). And, it was found that team members' cultural intelligence, trust and maturity (resources) was a requirement for adequate engagement and functioning in a virtual team. Each of the emic focused theme has been elaborated below.

\subsection{Focus on Goal Clarity}

Senior Marketing Director (London): It is about setting the expectations and expected results upfront. It helps you and the individual to be clear on the deliverables. It is always easy to point somebody out when they are not doing the right thing. And in GVTs, this takes high priority due to lack of personal and face to face interaction.

This theme highlights the importance of being structured in setting expectations and deliverables, and on putting conscious efforts by team members towards structuring the forms of working. The team members also emphasise periodic meetings using technology like video/audio conferencing, or calls to discuss the progress of team work. Increased frequency in regular meetings allows compensating for lack of physical interaction among team members of GVTs.

Senior Sales Manager (Kuala Lumpur): We properly define challenges and action plan every week. And, every week we also have a meeting with the senior management and update them about the progress. So, no progress means I am sitting at home!

Senior Project Manager (India): As a manager, one has to ensure that the team is working on a single goal. It becomes very important while working in a virtual team.

While in a collocated team it is also possible to work with less structure and do unplanned meetings on a need basis, participants emphasise that in GVTs, unstructured and unplanned meetings and discussions cannot be undertaken due to the dispersion of the team temporally and spatially. Thus periodic meetings and constant reiteration of goals help build clarity on goals which helps members of GVT to bring their cognitive and behavioural selves to work on goals important to the GVT. 


\subsection{Coordination Issues:}

Senior Project Manager (India): GVTs face on-site and off-site issues. I was once working from New York, and my team was in India. Due to the change in time zones, we faced a lot of difficulty in getting support from each other. And when I was back in India, the process of follow-up was also difficult.

Most participants stated that owing to contextual challenges of GVTs, coordination is a challenge faced by team members and managers of GVTs.

Vice President Sales (London): Most of the members get involved 7/24 with the team. Some of my team is in far-off Europe. It so happens sometimes that they forget other team members who are based out of their offices in their emails. These situations reduce coordination within the team. Some team members feel left out. So, out of sight, out of mind situation often occurs in GVTs.

The members also emphasised that interdependency of team members in GVTs is very high. Even though members seem to be independently working from different geographical locations, sensitisation of members towards better coordination reduces emotional and behavioural fallouts and thus eases the functioning of GVTs.

\subsection{Cultural Diversity:}

Senior Vice President, Business Unit Head (India): There was one person who I worked with in Germany, she was a fantastic contributor who had taken significant responsibility and did that very well. During one of the feedback sessions, when I asked her what are the things we can do better and how is she coming along, one thing that she said was, during the initial days, she was actually thinking of leaving the organisation, because she felt so disrespected in the conference calls. She said that "everybody is talking over me, and that is not something that I am used to". And also said, if somebody is talking, you finish that conversation, you hear that person, and then you make a point, and then the next person makes a point Right, she is very used to that. She had not worked in a global team before but she said that it took time for her to understand that this is the way that people talk, (sic) even though she could never understand the reason behind it.

The culture of 'structure and rigidity' in the West and that of 'flexibility and chaos' in the East has been highlighted by most participants, and they focus on the clutter that happens when these two cultures are to work along with each other in GVT context. Our study found that to cope with cultural sensitivity issues, managers have their own adaptive strategies- either the manager goes for a detailed 'background study' or 'contact switching'. Contact switching is to speak the same language in the accent of the receiver.

Sales Manager (Singapore): The only thing I had to do was contact switching. By contact switching what I mean is even though I am speaking English, I speak in a different way, so they understand. So this is what is contact switching. And it works well.

The majority of participants of this study emphasised challenges of cross-cultural environment in GVTs. And, therefore, being sensitive to cultures, local festivals, diversity of a team, and being flexible to team members' cultures facilitates working in GVTs. The participants also reflect that the multicultural nature of GVTs makes driving change a challenging task as 
different cultures have different mindsets and have different factors for getting motivated. Language and email etiquette have been stressed by the participants. Being careful with words while responding to emails can lessen the perceptual differences and misinterpretations of expectations in a GVT. Thus understanding and respecting cultural differences may enhance the cognitive, emotional and behavioural contributions of members of GVTs.

\subsection{Team Member Trust and Maturity}

The participants emphasised the role of trust in GVTs. GVTs require additional levels of trust due to lack of $\mathrm{FtF}$ interactions. It has been said that the need to build trust comes from the need to be dependent on the team members in GVTs, especially so when members have not seen or met each other in person.

General Manager (India): In GVTs, the relationships are built only on trust. Everyone wants to be a part of a winning story. Due to spatial dispersion, a lot of communication can go wrong due to lack of trust.

Design Engineer (West Perth): People take trust and give it back to you. I am here, and my team is in India. Coordinating in different time zones is only possible if I can trust that my team is there to support me.

Further, several members emphasised the need for team members to be mature enough to be able to handle the nuances and challenges of GVTs. All participants pinpointed the need to be self-managed rather than being micro-managed by managers in GVTs.

Associate Vice President (East Hartford): there are some people who will find it difficult to work in a GVT because here at the end of the day you are not answerable to your manager, you are answerable to the goals, and you are answerable to the outputs that you have to come up with.

Thus when team members are mature and are able to build trust amongst each other, we expect that they would be able to bring their complete selves towards the performance in GVTs.

\subsection{Technology Medium}

Senior Vice President, BU Head (India): Technology is an integral part of even having GVTs. If you are not connected on a very regular basis, GVTs cannot work.

All participants unanimously pointed out that the existence of GVTs depends on technology. Technology is the tool to collaborate, progress, enable and stay connected in GVTs. The choice of virtual infrastructures such as video conferencing, skype calls, phone or email is dependent on context, and type of communication and task required for the team members. Most connections are through email.

Vice President (London): I think a lot of this has to depend on what I call the virtual infrastructure. It is very important in GVTs that you have the proper tools, means to connect to the company, means to extract the data and put it back, and means to talk to different people in your team.

Also, it has been noted that most participants mention reduced cost due to the existence of virtual forms of work.

Sales Manager (Singapore): Technology has also enabled us to reduce the commuting through flights, back and forth etc. 
Apart from being an enabler, technology has also surfaced as a deterrent in GVTs, where it was noted that hiding information is easier in GVTs compared to a collocated team. The functioning of GVTs depends on a network of communication. The strength of connection determines the quality of communication. The lags in responses due to technology, the problems of transferring large files, and the problem of hiding behind text messages and email communication have emerged as challenges of technology through these interviews. Alongside the technical issues, technology also demands more individual efforts by team members to build interpersonal connections among team members. The interviews highlight that in GVTs the team members need to put extra efforts to connect, bond and understand each other. They need to overcome problems faced by team members due to lag in response, language misinterpretation, and bad networks. It has been noted that millennials are more comfortable and excited to work in GVTs as they are also digital natives compared to their seniors.

\subsection{Conflicts:}

Senior Project Manager (India): There is conflict, but the problem in a GVT is more difficult to identify. But, conflict does exist. And when you get into conflict, personally, I have not been successful in doing it while (sic) video conference. You have to get together and sort it up.

Most members interviewed view conflict management as one of the most important challenges as it just brews inside and does not surface. This, according to the participants, complicates the ways of working and compounds the challenges faced in GVTs by withholding or hiding information and this we feel as hindrance in team members to contribute fully in GVTs.

Design Engineer (India): A lot of times, when conflict gets into GVTs, that becomes unproductive for work, one has to have a face to face meeting with people in conflict and resolve it. It is very difficult to resolve it in a virtual environment.

\subsection{Interpersonal Relationships}

Vice President (London): [...] one is you get to know each other when you form GVTs and you are talking for the first time. Of course, through formal communication, you get to know each other, some of the details. But then informal communication happens when you send an email and you agree and put a small smiley. This helps in building interpersonal relationships in a virtual environment.

The participants working in GVTs mention that interpersonal skills are needed to adapt to conditions of GVTs. Skills that include writing emails, the etiquette of communication over technological media, and being sensitive in usage of words in text and email messaging have been mentioned. Apart from the above skills, it has also been emphasized that having adequate knowledge regarding the cultural and national background of the team member helps in building better interpersonal relations.

Senior Vice President (India): If one has done their homework and understand that there are circumstances and situations that could be impacting the other person differently, then, communication with the other person helps build better interpersonal relationships with the members who are geographically dispersed. This will in a way allow to reduce the distance between the locations (sic). 


\subsection{Informal Communication}

It has been found in this study that informal communication among members of GVTs allows them to get to know each other better and increases 'team bonding' given the challenge of not being able to meet on a daily basis.

Senior Marketing Director (Singapore): I think it is important for a team to understand and also getting that additional information (through informal communication) is always helpful.

Design Engineer (India): I think it is important for a team to understand and also getting that additional information (through informal communication) is always helpful.

Further, participants specify that informal communication is difficult in GVTs as FtF interactions are reduced and, further, communications which occur outside the work boundaries in a collocated team are less possible in a virtual context. The participants specially mention that in GVTs the social needs are seldom fulfilled. The getting together of teams or meeting team members personally during lunch and snack time are extensively reduced. The team members have been noted to feel isolated and left out, and also crave for belongingness. They also feel that positive energy is missing in teams while sharing concerns, and discussion of personal grievances are also reduced. Such experiences by the participants lead to higher emotional exhaustion rather than physical exhaustion in GVTs. The lesser experience of emotions, belongingness, and appreciation is a norm when one is part of GVTs.

\subsection{Temporal Distance}

According to participants, one of the biggest challenges in GVTs is to understand and collaborate with people across time zones. It takes effort, patience, and persistence to coordinate the timings of all members of the team for a discussion, meeting, or a brainstorming session to be scheduled. If for any reason, the coordination fails for a particular time zone, team members would lose interest and disengage from subsequent discussions in teams.

Senior Vice President (India): It sometimes happens that team members located outside of the headquarters, or outside of the location wherever the leader is located is, there is a tendency for teams who are in one location to just start brainstorming an idea, come up with something, some sort of a draft etc., and then go to GVTs or teams outside of that headquarter or teams outside of that geography and ask them for their feedback. The teams which are (sic), they don't see anything wrong in that, we are soliciting inputs, we are making this part, but the problems with (sic) the teams outside see is that we want to be in the brainstorming meeting.

Even though the participants had reported having experienced challenges while working in GVT context, they have also stated that GVTs give them autonomy of work, reduce distraction and allow higher immersion and dedication towards the job, and contribute towards advancing their career. A Design Engineer (India) shared an experience which involved high levels of commitment and loyalty towards the GVT she was working with, and another Senior Vice President (India) shared his view that in GVTs, "the team members are loyal towards the leader or team more than the organisation due to lesser impact of organisational culture in GVTs." 


\section{The Conceptual Model}

We use emic descriptions and concerns expressed by the participants to derive etic categorisations of drivers of employee engagement using the Job Demands-Resources theory of employee engagement. The JD-R (Bakker \& Demerouti, 2014, 2017, 2018) suggests that all job characteristics can be classified as either Job Demands or Job Resources. Job demands are those aspects of work which cost energy of the employee; and job resources are those aspects of work which enable employees to deal with the job demands and achieve their goals (Bakker \& Demerouti, 2018). Job demands also are known to have an independent effect on employee well-being and, in contrast, job resources are known to initiate a motivational effect (Scaufeli \& Bakker, 2004). Job resources can also buffer the impact of job demands on the negative strain. Even though each of them have an independent impact, they also work in concert.

Existing research indicates that employees actively interpret and influence their working conditions (Bakker \& Demerouti, 2018). Based on employee's occupational health, they can influence their job designs either into a loss cycle or a gain cycle. When employees are stressed, they influence their work environment negatively and are susceptible to lose even more resources leading to a loss cycle; and when motivated and engaged, they influence their environment in a positive way leading to gain cycles (Bakker \& Demerouti, 2018). The job demands are increased with high levels of job strain (chronic exhaustion), poor communication, mistakes in structure, and conflicts among team members, and these behaviours have been termed as 'self-undermining' as they lead to reduced performance (Bakker \& Demerouti, 2018). The employees who experienced increased levels of job strain are noted to be engaged in self-undermining behaviours and report higher levels of emotional exhaustion, demands and lower performance (Bakker \& Wang, 2016). Those employees with positive job resources such as craftsmanship, pride in the profession, and positive feedback of their work have been said to positively influence work engagement which, in turn, positively impact future job resources (Hakanen, Perhoniemi, \& Toppinen-Tanner, 2008). In case of GVTs, academic literature, practitioner literature, and phenomenological accounts in this study identify the challenges which can be experienced as job demands by team members in comparison to collocated teams such as temporal and spatial dispersion, reduced interpersonal relationships, probability of higher conflicts, and reduced FtF interactions. The emic interpretations of this study also underline the additional challenges of a technological medium, need for higher trust and maturity levels of individuals involved, and the importance of cultural intelligence among team members. The emic interpretations are evident to the challenges faced by GVT members and the available job resources for similar job demands as a collocated team. This comparison may lead to an increase in loss cycles of team members compared to gain cycles. The mismatch in the form of higher job demands and limited job resources in the context of GVTs necessitates a detailed understanding of employee engagement in GVTs.

Our findings indicate that the challenges of employee engagement according to prior scholarly literature in the context of the collocated team is significantly different in comparison to challenges experienced by the participants in this study.

We argue that the context of GVTs is unique-it is virtual, technology-driven and multiculturaland, hence, these contextual features could be perceived as job demands to be additionally met by members of GVTs. If perceived as job demands these specific factors could negatively influence the employee's cognitive, emotional and behavioural contribution towards 
organisational goals. Thus, it becomes prudent for organisations to understand and invest in creating job resources that would help GVT members to overcome the job demands and consequently increase employee engagement. The emic interpretations derived based on this study are mapped with the etic categorisations as shown in Table 2. Figure 2 is the derived conceptual framework based on these emic and etic interpretations which are discussed in the subsequent section.

\section{Drivers of Employee Engagement in GVTs}

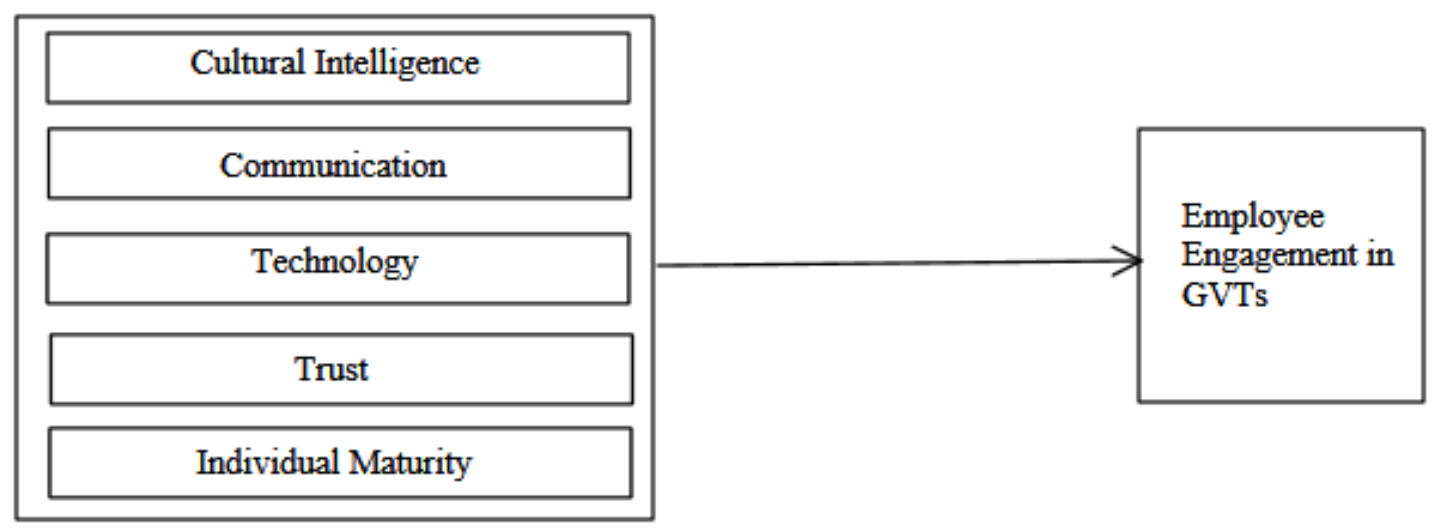

Figure 2: Drivers of Employee Engagement in GVTs - Etic Interpretation. (Framework: by authors)

\begin{tabular}{|c|l|l|}
\hline S.No & \multicolumn{1}{|c|}{ Emic Interpretations } & \multicolumn{1}{c|}{ Etic Categorizations } \\
\hline 1 & Focus on Goal Clarity & Communication (formal) \\
\hline 2 & Conflicts & Communication (informal) \\
\hline 3 & Interpersonal Relationships & Communication (informal) \\
\hline 4 & Informal Communications & Communication (informal) \\
\hline 5 & Cultural Diversity & Cultural Intelligence \\
\hline 6 & Team Member Trust \& Maturity & Trust \& Maturity (separated) \\
\hline 7 & Technology Medium & Technology \\
\hline 8 & Coordination Issues & Technology \\
\hline 9 & Temporal Distance & Technology \\
\hline
\end{tabular}

Table 2: Mapping of Emic interpretations into Etic themes

\subsection{Cultural Intelligence}

The findings of this phenomenological account reflect the need for cultural sensitivity or cultural awareness in GVTs and, in our opinion, the Cultural Intelligence/ Cultural Quotient (CQ) construct captures individual sensitivity towards the different cultures. As per Ang et al. (2007), CQ emphasises metacognitive, cognitive, motivational, and behavioural facets of an employee to adapt and function in a multicultural environment. Thus, higher cultural intelligence of members in GVT act as a resource to overcome the barriers created due to cultural diversity as they would be more sensitive towards cultural differences. This has the potential to enhance emotional and behavioural contribution to the GVTs, through higher engagement.

In a traditional team setup, employees have sufficient physical interactions with their professional counterparts, which might lead to distinct and clearer differentiation between 
their work and non-work identities (national, gender, family). As the context of work changes in a GVT, and with blurring distinctions between work and non-work life identities, employees in such occupations tend to negotiate between work and non-work identities. In case of GVTs, where team members belong to varied geographical locations, with a diverse set of cultural background, it is highly likely that due to lesser physical interactions and lesser rich mediums of communication, employees could be more aligned towards their non-work identities than the work identities (Ramarajan \& Reid, 2013). In a GVT, it is possible that the impact of the cultural background of an employee is more pronounced and national culture prompts employees to form sub-groups within a team, as a process of self-categorisation, and, thus, social identification. Individual well-being and engagement; occupational productivity and efficiency; and individual empowerment and autonomy have been mentioned as three direct consequences of alignment of work and non-work identities of an employee at the workplace (Ramarajan \& Reid, 2013). Due to distorted alignment, the employees in a GVT might not be able to express themselves cognitively, emotionally or physically as there is a lack of cultural understanding and confused identity. We propose that when team members express higher cultural intelligence, the alignment of non-work and work identities could create better understanding, fewer conflicts, and improved interpersonal relationships, (Ang, Van Dye, Koh, \& Ng, 2007). This has also been captured in the phenomenological accounts of this study. These could be perceived as job resources by members of GVTs leading to higher levels of engagement. Therefore, we propose that:

Proposition 1: Cultural intelligence of team members positively influences employee engagement in GVTs.

\subsection{Communication}

From excerpts in the emic descriptions, it is evident that in GVTs, structured, frequent and formal communication on expectations and deliverables helps to build goal clarity among GVT members which could be perceived as a valuable job resource by employees. On the other hand, informal communication is less prevalent and, therefore, to build cultural awareness, bonding, and faith, it is very essential for a team to also have communication which is not work-related. This could help culturally diverse members of GVTs to understand each other better. Informal communication is something that happens spontaneously (Kraut, Fish, Root, \& Chalfonte, 1990). And this could include communication which is unscheduled, interactive, spontaneous, optional, participant organised, and experience focused (Flepp et al., 2017; Hrastinski, 2010). Earlier research has found that informal communication in a team is very essential for its successful collaboration (Fish, Kraut, Root, \& Chalfonte, 2002). In GVTs, accomplishment of team tasks inadvertently involves collaboration. Thus, informal communication gains prominence. This study emphasises that informal communication helps the members' understanding of their teamwork and learning about each other. And, by doing this, due to the underlying social relations, it gives critical facility and resources for engagement and for collaborators to jointly work, maintain and also drive to conclusions (Fish et al., 2002). Another added advantage for informal communication is that it helps to understand and empathise with time zone differences and different expectations of diverse team members. It helps in understanding other members' challenges, and to structure the formal communication and scheduling when working in a virtual environment in such a way that participants converge with time zones differences and are flexible in their approach. Therefore, appropriate communication, both formal and informal, act as resources to help 
overcome the challenges in GVTs, and negate the demands of the job for GVT members to be cognitively, emotionally and physically immersed in their work. Hence, it is proposed that:

Proposition 2: Formal and informal communication among the team members positively influences employee engagement in GVTs.

\subsection{Individual Maturity}

Our analysis in previous section indicate the advantage of having mature team members in GVTs. According to Argyris (1957), "as a person matures, changes occur in several continua which include passive to active, dependence to independence, behave in few ways to capable of behaving in many ways, erratic shallow interest to deep strong interest, short-term perspective to long-term perspective, subordinate position to equal (or) superordinate position, and, lack of awareness of self to awareness and control of self" (as cited in Eldridge, 1991). Such maturity on part of members of GVTs would serve several benefits. Further, for a GVT to work in coordination and alignment, it is necessary to have all team members as a single cohesive unit which allows them to use their skills and capabilities and motivate them towards concerted actions. Team technical competency, team motivation, and virtual teamwork skills have been identified as dimensions of team maturity in GVTs (Zhang, Tremaine, Fjermestad, Milewski, \& O'Sullivan 2006). In the analysis of our phenomenological accounts, we found that managers in GVTs would prefer an individual who either has experience of working in a GVT or an individual with very high commitment levels. By the term 'mature', they meant that team members have high cognition towards their jobs. According to Shuck (2010), employee engagement is "cognitive, emotional and behavioural". We argue that the maturity of team members in GVTs helps in team functioning, influencing the cognitive and emotional aspect of employee engagement. Thus, we propose:

Proposition 3: Maturity of team members positively influences employee engagement in GVTs.

\subsection{Trust}

Trust, openness, and honesty are seen as critical factors by team managers and also by team members when they are part of GVTs. However, in GVTs it may take time to build trust due to geographical dispersion, limited informal communication, diverse cultural background, language barriers and so on. Most participants in the interviews pointed that at least one FtF conversation, or a video conference where the team has visual images of people they are talking to, will be helpful in building a relationship and extending collaboration in GVTs. Thus, building trust is one of the critical challenges faced in GVTs (Chatfield, Shlemoon, Redublado, \& Darbyshire, 2014). Trust as a topic of research has been widely studied in the context of GVTs (Bell \& Kozlowski, 2002a; Jarvenpaa \& Leidner, 1998; Krebs, Hobman \& Bordia, 2006). As discussed earlier, informal communication can be one of the means to build trust in GVTs. In addition, structured and clear communication of goals allows the teams to be in alignment with their broader objective. Trust enables alignment of common goals and reduces conflicts which can be highly prominent in GVTs (Panteli \& Sockalingam, 2005). The reduction of conflicts in GVTs can lead to improved performance as team members share information across among team members which can be beneficial (Panteli \& Sockalingam, 2005). The employees can thus focus more, both cognitively and emotionally, on their job rather than be in conflict with other team members. In view of the above, we propose that,

Proposition 4: Trust among team members positively influences employee engagement in GVTs. 


\subsection{Technology}

The very existence of GVTs is based on the presence of technology media connecting team members across geography. Technology plays a vital role in many forms such as text, email, instant messaging (IM), video conferencing, WebEx, phone calling and so on (Chatfield, Shlemoon, Redublado, \& Darbyshire, 2014). The selection of technology depends on the type of task. More complex tasks require more coordinated and interactive effort. Team members' roles become highly symbiotic and the need for deeply orchestrated teamwork, reciprocal communication and feedback are essential (Bell \& Kozlowski, 2002). In complex tasks, information richness becomes critical and necessary due to collaboration demands (Hollingshead, Mcgrath, \& O'Connor, 1993). Straus and McGrath (1994) found that there was no difference between $\mathrm{FfF}$ and technology-mediated groups in lower complexity tasks. However, FtF teams performed significantly better than their technology-mediated counterparts in more complex and judgmental tasks. Bell and Kozlowski (2002) opined that synchronous forms of communication are superior to asynchronous modes for complex tasks which require collaborating and a lot of information sharing. They suggest that these technologies in synchronous form maintain a higher degree of information richness and allow interactive decision-making mechanisms, leveraging collaboration and coordination. Media effects are generally a combination of the technical capabilities of the communication media, the group's understanding of the medium and their usage according to the purpose (DeSanctis, Poole, Dickson, \& Jackson 1993). Even though media effects depend on user experience as well as technical capabilities of the members, use of technology-mediated communication without $\mathrm{FtF}$ interaction can change the dynamics of team relationships, and misunderstandings, if any, might be hidden longer in GVTs than in traditional settings (Hansen, 2004). While diversity of a geographically distributed team might stimulate creativity allowing a wide variety of skills, it might also reduce cohesion in the team (Kankanhalli, Tan, \& Wei, 2007). The selection of technology, either synchronous or asynchronous, becomes important in the context of GVTs. When appropriate technology is not selected there is a chance of misinterpretation of the message, and misunderstanding among the team members which can increase the risk of reduced levels of trust and increased conflicts (Knight \& Burn, 2011; Yigitbasioglu; 2014). The reflections on the phenomenological accounts also suggest that technology enables the working of GVTs but the use of appropriate technology is important which enables smooth functioning of GVTs by reducing the challenge of misinterpretation and misunderstanding among team members, facilitating team members to be cognitively and emotionally driven towards performance. Hence, we propose:

Proposition 5: Appropriate technology positively influences employee engagement in GVTs.

Based on our findings, we conceptualise that employee engagement in GVTs could be influenced by the cultural intelligence of team members, formal and informal communication in GVTs, greater maturity of team members, higher trust levels in team members and appropriate technological support.

\section{Discussion and Implications}

There has been an extensive study on employee engagement both in practitioner and academic literature, however, there is a scant literature which tries to understand employee engagement in the context of GVTs. The purpose of this study was to understand the experiences of team members of GVTs and then derive the drivers of employee engagement in GVTs and compare 
these with traditional collocated team context. Our findings and interpretive analysis at two levels- emic and etic- reveal that in the context of GVTs, the drivers of employee engagement take newer meaning and form. With the use of phenomenology, we make an attempt to understand the phenomenon of employee engagement through the narratives and stories of lived experiences of members of GVTs. This is a seminal study (in our knowledge, it could be the first) to understand drivers of employee engagement in GVTs using phenomenology. Using the JD-R model, we argue that in the context of GVTs, the job demands are unique and, hence, there is a need to transform some of these demands into resources or to negate the effects of few of the demands (e.g. cultural intelligence in GVT members can negate the negative influence of cultural misunderstandings). Thus, by working on factors like technology, communications, trust, maturity, and cultural intelligence, GVTs members' perception of resources would increase, thus, making them increase their cognitive, emotional and behavioural contributions towards the team goals through higher levels of engagement. The importance of cultural intelligence (Erez et al., 2013), technological competence (Carlson, Carlson, Vaughn, \& George, 2017; Chatfield et al., 2014), individual maturity (Friedrich, Friedrich, \& Fetzer, 2017), informal communication (Marlow, Lacerenza, \& Salas, 2017) and trust among team members in GVT (Alsharo, Gregg, \& Ramirez, 2017; Chatfield et al., 2014) have been studied earlier with their direct linkages to effective functioning of GVTs. However, we conceptualise the relationship between the drivers and GVT success could be facilitated through the process of employee engagement. Thus, we argue that for an employee to contribute towards GVT goals he/she needs to be engaged and for an employee to be engaged in the context of a GVT, the combination of these five drivers play an important role in helping members perceive the specific context of the GVT as an enabler, instead of a hindrance in performance in GVTs. The results of this study demonstrate that when the context of team environment changes to being virtual, multicultural and technology-mediated, the challenges that the team members face in being engaged change. These challenges need to be addressed with adequate resources for the team members to be cognitively, emotionally and physically directing their energy towards their performance. This study involved understanding the lived experiences of employees as they engage in GVTs and, thus, it adds to the academic literature by highlighting five possible factors that could drive employee engagement in GVTs. On theoretical grounds, the study contributes to literature on GVTs and the literature on employee engagement. This study also offers guidelines to practitioners on ways to improve employee engagement in a virtual context. As the practitioner literature, for example, Aon Hewitt (2013) or KPMG (2012), claim reduced levels of engagement in GVTs, this study provides a direction towards improving engagement in GVTs by providing appropriate technology support, and facilitating adequate informal and formal communications among team members. The GVTs would gain by investing in improving the cultural intelligence of team members and providing appropriate opportunities to build trust among members.

\section{Conclusion and Limitations}

This study was an attempt to understand employee engagement in GVTs as recent times have witnessed a proliferous increase in globally distributed teams due to rapid growth of technology and globalisation. Our interpretive analysis highlights that in order to increase engagement levels in GVTs, organisations need to focus on appropriate team membership (members high in maturity and cultural intelligence) supported by appropriate technology, and adequate formal and informal communication. Finally, facilitating teams to create a 
climate of trust among members might help in fostering an environment in GVTs which is ultimately engaging.

This study has several limitations which we propose to address in further studies. The drivers have been derived through the interpretive analysis of narratives by members of GVTs while describing their experiences in GVTs, and, hence, linkages with employee engagement have not been studied directly. We acknowledge the need to take this research forward by individually and collectively testing the variables conceptualised in this study through larger empirical study in multiple organisations. The subjective interpretations of the interpretations of the experiences of the participants by researchers add to the subjectivity in our conclusions and, hence, may not be infallible. We believe that an empirical testing of variables will help concretise conceptual variables with certainty, especially by showing full or partial mediation of employee engagement between the variables and effective functioning of the GVTs. Also, due to the use of many modes of technology for conducting interviews, the bias due to multiple media can be questioned. Going forward, an empirical study will enable us to concretise the drivers of employee engagement in GVTs conceptualized in this study.

\section{References}

Alarcon, G. M. (2011). A meta-analysis of burnout with job demands, resources, and attitudes. Journal of Vocational Behavior, 79(2), 549-562.

Albrecht, S. L., \& Anglim, J. (2018). Employee engagement and emotional exhaustion of fly-infly-out workers: A diary study. Australian Journal of Psychology, 70(1), 66-75.

Albrecht, S. L., Bakker, A. B., Gruman, J. A., Macey, W. H., \& Saks, A. M. (2015). Employee engagement, human resource management practices and competitive advantage: An integrated approach. Journal of Organizational Effectiveness: People and Performance, 2(1), 735.

Alnuaimi, O. A., Robert, L. P., \& Maruping, L. M. (2010). Team size, dispersion, and social loafing in technology-supported teams: A perspective on the theory of moral disengagement. Journal of Management Information Systems, 27(1), 203-230.

Alnuaimi, O. A., Robert, L. P., \& Maruping, L. M. (2010). Team size, dispersion, and social loafing in technology-supported teams: A perspective on the theory of moral disengagement. Journal of Management Information Systems, 27(1), 203-230.

Alsharo, M., Gregg, D., \& Ramirez, R. (2017). Virtual team effectiveness: The role of knowledge sharing and trust. Information \& Management, 54(4), 479-490.

Ang, S., Van Dyne, L., Koh, C., Ng, K. Y., Templer, K. J., Tay, C., \& Chandrasekar, N. A. (2007). Cultural intelligence: Its measurement and effects on cultural judgment and decision making, cultural adaptation and task performance. Management And Organization Review, 3(3), 335-371.

Argyris, C. (1957) Personality and organization: The conflict between system and the individual. New York: Harper \& Row.

Bailey, C., Madden, A., Alfes, K., \& Fletcher, L. (2017). The meaning, antecedents and outcomes of employee engagement: A narrative synthesis. International Journal of Management Reviews, 19(1), 31-53. 
Bakker, A. B., \& Demerouti, E. (2007). The job demands-resources model: State of the art. Journal Of Managerial Psychology, 22(3), 309-328.

Bakker, A. B., \& Demerouti, E. (2014). Job demands-resources theory. Wellbeing: A Complete Reference Guide, 1-28.

Bakker, A. B., \& Demerouti, E. (2017). Job demands-resources theory: Taking stock and looking forward. Journal of Occupational Health Psychology, 22(3), 273.

Bakker, A. B., \& Demerouti, E. (2018). Multiple levels in job demands-resources theory: Implications for employee well-being and performance. Handbook Of Well-Being. Salt Lake City, UT: DEF Publishers. DOI: nobascholar.com.

Bakker, A. B., \& Wang, Y. (2016). Self-undermining behaviour at work: Evidence of construct and predictive validity. Manuscript submitted for publication.

Bell, B. S., \& Kozlowski, S. W. (2002). A typology of virtual teams: Implications for effective leadership. Group \& Organization Management, 27(1), 14-49.

Bhoola, V., \& Giangreco, A. (2018). HR activities and practices for project success: A multimethod approach from Indian IT firms. Australasian Journal of Information Systems, 22.

Burgess, K., Kerr, D. V., \& Houghton, L. (2013). Paradigmatic approaches used in enterprise resource planning systems research: A systematic literature review. Australasian Journal of Information Systems, 18(1).

Burn, J., \& Robins, G. (2002). A Virtual Organisation Model for E-Government. Australian Journal of Information Systems, 9(2), 104-112.

Carlson, J. R., Carlson, D. S., Hunter, E. M., Vaughn, R. L., \& George, J. F. (2017). Virtual team effectiveness: Investigating the moderating role of experience with computer-mediated communication on the impact of team cohesion and openness. In Remote Work and Collaboration: Breakthroughs in Research and Practice (pp. 687-706). IGI Global.

Chatfield, A., Shlemoon, V. Najem., Redublado, W. \& Darbyshire, G. (2013). Creating value through virtual teams: a current literature review. 24th Australasian Conference on Information Systems (pp. 1-11). Australia: RMIT University.

Christian, M. S., Garza, A. S., \& Slaughter, J. E. (2011). Work engagement: A quantitative review and test of its relations with task and contextual performance. Personnel Psychology, 64(1), 89-136.

Cole, M. S., Walter, F., Bedeian, A. G., \& O’Boyle, E. H. (2012). Job burnout and employee engagement: A meta-analytic examination of construct proliferation. Journal of Management, 38(5), 1550-1581.

Connaughton, S. L., \& Shuffler, M. (2007). Multinational and multicultural distributed teams: A review and future agenda. Small Group Research, 38(3), 387-412.

Crawford, E. R., LePine, J. A., \& Rich, B. L. (2010). Linking job demands and resources to employee engagement and burnout: a theoretical extension and meta-analytic test. Journal Of Applied Psychology, 95(5), 834.

Crawford, E. R., Rich, B. L., Buckman, B., \& Bergeron, J. (2013). The antecedents and drivers of employee engagement. In Employee Engagement In Theory And Practice (pp. 71-95). Routledge. 
Demerouti, E. (2014). Design your own job through job crafting. European Psychologist,19, pp. 237-247

Demerouti, E., Bakker, A. B., Nachreiner, F., \& Schaufeli, W. B. (2001). The job demandsresources model of burnout. Journal Of Applied Psychology, 86(3), 499.

DeSanctis, G., Poole, M. S., Dickson, G. W., \& Jackson, B. M. (1993). Interpretive analysis of team use of group technologies. Journal of Organizational Computing and Electronic Commerce, 3(1), 1-29.

Dulebohn, J. H., \& Hoch, J. E. (2017). Virtual teams in organizations. Human Resource Management Review, 27(4), pp. 569-574.

Eldridge, W. D. (1991). The challenge of maturity: a comprehensive guide to understand and achieve psychological and social self-actualization as we grow older. University Press of America.

Erez, M., Lisak, A., Harush, R., Glikson, E., Nouri, R., \& Shokef, E. (2013). Going global: Developing management students' cultural intelligence and global identity in culturally diverse virtual teams. Academy of Management Learning E Education, 12(3), 330-355.

Fish, R. S., Kraut, R. E., Root, R. W., \& Rice, R. E. (1993). Video as a technology for informal communication. Communications of the ACM, 36(1), 48-61.

Flepp, C., Imhof, M., Meier, G., Ryser, T., Burkhard, R., Schulze, H., \& Simon, A. (2017). Designing Rooms for Virtual, Informal Communication: Reciprocal Awareness as a Central Criterion. In Advances in Ergonomic Design of Systems, Products and Processes (pp. 191-208). Springer, Berlin, Heidelberg.

Friedrich, R., Friedrich, R., \& Fetzer. (2017). Virtual Team Maturity Model. Springer.

Gibson, C. B., \& Gibbs, J. L. (2006). Unpacking the Concept of Virtuality?: The Effects of Geographic Dispersion, Electronic Dependence, Dynamic Structure, and National Diversity on Team Innovation Author(s): Cristina B . Gibson and Jennifer L . Gibbs Published by: Sage Publications , , 51(3), 451-495.

Gilson, L. L., Maynard, M. T., Jones Young, N. C., Vartiainen, M., \& Hakonen, M. (2015). Virtual teams research: 10 years, 10 themes, and 10 opportunities. Journal of Management, 41(5), 1313-1337.

Grenny, J., Maxfield, D. (2017, November). A study of 1100 employee found that remote workers feel shunned and left out. Harvard Business Review, Retrieved from blob:https://hbsp.harvard.edu/aece0f82-a45b-49ad-9482-0d2703e2dcf2

Haas, M. R. (2006). Acquiring and applying knowledge in transnational teams: The roles of cosmopolitans and locals. Organization Science, 17(3), 367-384.

Hakanen, J. J., Perhoniemi, R., \& Toppinen-Tanner, S. (2008). Positive gain spirals at work: From job resources to work engagement, personal initiative and work-unit innovativeness. Journal Of Vocational Behaviour, 73(1), 78-91.

Hakanen, J. J., Schaufeli, W. B., \& Ahola, K. (2008). The Job Demands-Resources model: A three-year cross-lagged study of burnout, depression, commitment, and work engagement. Work E Stress, 22(3), 224-241. 
Halbesleben, J. R. (2010). A meta-analysis of work engagement: Relationships with burnout, demands, resources, and consequences. Work engagement: A handbook of essential theory and research, 8(1), 102-117.

Hansen, M. (2004). Virtual teams that work: Creating conditions for virtual team effectiveness. Personnel Psychology, 57(1), 243.

Heidegger, M., Macquarrie, J., \& Robinson, E. S. (1962). Being and Time. Translated by John Macquarrie \& Edward Robinson.(First English Edition.). London

Henry, J.E. and Hartzler, M. 1998. Tools for Virtual Teams. Milwaukee, WI: ASQ Quality Press.

Hewitt, A. (2005). Trends in Employee Engagement. Aon Hewitt Corp, 18, Retrieved from: http://aon.mediaroom.com/news-releases?item=62745, August 23, 2018.

Hoch, J. E., \& Kozlowski, S. W. (2014). Leading virtual teams: Hierarchical leadership, structural supports, and shared team leadership. Journal Of Applied Psychology, 99(3), 390.

Hollingshead, A. B., McGrath, J. E., \& O'Connor, K. M. (1993). Group task performance and communication technology: A longitudinal study of computer-mediated versus face-toface work groups. Small Group Research, 24(3), 307-333.

Hrastinski, S. (2010). How do e-learners participate in synchronous online discussions? Evolutionary and social psychological perspectives. In Evolutionary psychology and information systems research (pp. 119-147). Springer, Boston, MA.

Husserl, E. (1962). Ideas, trans. WRB Gibson, New York, Collier, 270.

Jarvenpaa, S. L., \& Leidner, D. E. (1998). Communication and trust in global virtual teams. Journal Of Computer-Mediated Communication, 3(4), JCMC346.

Jarvenpaa, S. L., \& Leidner, D. E. (1999). Communication and trust in global virtual teams. Organization Science, 10(6), 791-815.

Jimenez, A., Boehe, D. M., Taras, V., \& Caprar, D. V. (2017). Working across boundaries: Current and future perspectives on global virtual teams. Journal of International Management, 23(4), 341-349.

Jopling, D. A. (1996). Sub-phenomenology. Human Studies, 19(2), 153-173.

Kahn, W. A. (1990). Psychological conditions of personal engagement and disengagement at work. Academy of Management Journal, 33(4), 692-724. .

Kankanhalli, A., Tan, B. C. Y., \& Wei, K. K. (2007). Managing conflict in global virtual teams. Journal of Management Information Systems, 24(3), 237-274.

Knight, S. , \& Burn, J. M. (2011). A Preliminary Introduction to the OTAM: Exploring Users' Perceptions of their on-going Interaction with Adopted Technologies. Australasian Journal of Information Systems, 17(1), 5-41.

KPMG (2012). Rethinking human resources in a changing world. Retrieved from https://home.kpmg.com/content/dam/kpmg/pdf/2016/06/pl-rethinking-humanresources-in-a-changing-world.pdf

Kraut, R. E., Fish, R. S., Root, R. W., \& Chalfonte, B. L. (1990). Informal communication in organizations: Form, function, and technology. In Human reactions to technology: Claremont symposium on applied social psychology (pp. 145-199). 
Krebs, S. A., Hobman, E. V., \& Bordia, P. (2006). Virtual teams and group member dissimilarity: Consequences for the development of trust. Small Group Research, 37(6), 721-741.

Levy, S., (1981), "Interpreting Consumer Mythology: A Structural Approach to Consumer Behavior," Journal of Marketing, 54 (Summer), 49-61.

Macey, W. H., Schneider, B., Barbera, K. M., \& Young, S. A. (2009). Employee engagement: Tools for analysis, practice, and competitive advantage. Malden, WA: WileyBlackwell.

Macey, W. H., Schneider, B., Barbera, K. M., \& Young, S. A. (2011). Employee engagement: Tools for analysis, practice, and competitive advantage (Vol. 31). John Wiley \& Sons.

Marlow, S. L., Lacerenza, C. N., \& Salas, E. (2017). Communication in virtual teams: A conceptual framework and research agenda. Human Resource Management Review, 27(4), 575-589.

Maslach, C., Leiter, M. P., \& Schaufeli, W. (2008). Measuring burnout. In The Oxford handbook of organizational well being. Oxford

Maslach, C., Schaufeli, W. B., \& Leiter, M. P. (2001). Job burnout. Annual Review Of Psychology, 52(1), 397-422.

Matlay, H., \& Martin, L. M. (2009). Collaborative and competitive strategies in virtual teams of e-entrepreneurs: A pan-European perspective. Australasian Journal of Information Systems, 16(1).

McCracken, G., (1988), The Long Interview, Newbury Park, CA: Sage.

Morgan, L., Paucar-Caceres, A., \& Wright, G. (2014). Leading effective global virtual teams: The consequences of methods of communication. Systemic Practice and Action Research, 27(6), 607-624.

Mowshowitz, A. (2002). Virtual organization: Toward a theory of societal transformation stimulated by information technology. Greenwood Publishing Group.

O'Hara-Devereaux, M., R. Johansen. 1994. Global Work: Bridging Distance, Culture, and Time. Jossey-Bass San Francisco, CA

O'Leary, M. B., \& Cummings, J. N. (2007). The spatial, temporal, and configurational characteristics of geographic dispersion in teams. MIS Quarterly, 433-452.

Panteli, N., \& Sockalingam, S. (2005). Trust and conflict within virtual inter-organizational alliances: a framework for facilitating knowledge sharing. Decision Support Systems, 39(4), 599-617.

Peters, L., \& Karren, R. J. (2009). An examination of the roles of trust and functional diversity on virtual team performance ratings. Group \& Organization Management, 34(4), 479-504.

Pike, K. L. (1967). Etic and emic standpoints for the description of behaviour. In K. L. Pike, Language in relation to a unified theory of the structure of human behaviour (pp. 37-72). The Hague, Netherlands: Mouton \& Co. http://dx.doi.org/10.1037/14786-002

Powell, A., Piccoli, G., \& Ives, B. (2004). Virtual teams: a review of current literature and directions for future research. ACM SIGMIS Database: the DATABASE for Advances in Information Systems, 35(1), 6-36. 
Raghuram, S., \& Wiesenfeld, B. (2004). Work-nonwork conflict and job stress among virtual workers. Human Resource Management, 43(2-3), 259-277. https://doi.org/10.1002/hrm.20019

Ramarajan, L., \& Reid, E. (2013). Shattering the myth of separate worlds: Negotiating nonwork identities at work. Academy of Management Review, 38(4), 621-644.

Rich, B. L., Lepine, J. A., \& Crawford, E. R. (2010). Job engagement: Antecedents and effects on job performance. Academy Of Management Journal, 53(3), 617-635.

Saks, A. M. (2006). Antecedents and consequences of employee engagement. Journal Of Managerial Psychology, 21(7), 600-619.

Saks, A. M., \& Gruman, J. A. (2014). What do we really know about employee engagement?. Human Resource Development Quarterly, 25(2), 155-182.

Salanova, M., \& Schaufeli, W. B. (2008). A cross-national study of work engagement as a mediator between job resources and proactive behaviour. The International Journal of Human Resource Management, 19(1), 116-131.

Schaubroeck, J., \& Yu, A. (2016). When does virtuality help or hinder teams? Core team characteristics as contingency factors. Human Resource Management Review, 1-13. https://doi.org/10.1016/j.hrmr.2016.12.009

Schaufeli, W. B., \& Bakker, A. B. (2004). Job demands, job resources, and their relationship with burnout and engagement: A multi-sample study. Journal of Organizational Behavior: The International Journal of Industrial, Occupational and Organizational Psychology and Behavior, 25(3), 293-315.

Schutz, A. (1967). The phenomenology of the social world. Northwestern University Press.

Sherry, J. F. (1991). Postmodern alternatives: the interpretive turn in consumer research. Handbook Of Consumer Behaviour, 199, 548-591.

Shuck, B., \& Herd, A. M. (2012). Employee engagement and leadership: Exploring the convergence of two frameworks and implications for leadership development in HRD. Human Resource Development Review, 11(2), 156-181.

Shuck, B., \& Wollard, K. (2010). Employee engagement and HRD: A seminal review of the foundations. Human Resource Development Review, 9(1), 89-110.

Snow, C. C., Snell, S. A., Davison, S. C., \& Hambrick, D. C. (1996). Use transnational teams to globalize your company. Organizational Dynamics, 24(4), 50-67.

Stern, P. N. (1994). Eroding grounded theory. Critical Issues In Qualitative Research Methods, 212223

Straus, S. G., \& McGrath, J. E. (1994). Does the medium matter? The interaction of task type and technology on group performance and member reactions. Journal Of Applied Psychology, 79(1), 87.

Strauss, A., \& Corbin, J. M. (1990). Basics of qualitative research: Grounded theory procedures and techniques. Sage Publications, Inc. 
Thompson, C. J., Locander, W. B., \& Pollio, H. R. (1989). Putting consumer experience back into consumer research: The philosophy and method of existential-phenomenology. Journal Of Consumer Research, 16(2), 133-146.

Thompson, C. J., Locander, W. B., \& Pollio, H. R. (1990). The lived meaning of free choice: An existential-phenomenological description of everyday consumer experiences of contemporary married women. Journal Of Consumer Research, 17(3), 346-361.

Thompson, C. J., Pollio, H. R., \& Locander, W. B. (1994). The spoken and the unspoken: a hermeneutic approach to understanding the cultural viewpoints that underlie consumers' expressed meanings. Journal of Consumer Research, 21(3), 432-452.

Townsend, A. M., DeMarie, S. M., \& Hendrickson, A. R. (1998). Virtual teams: Technology and the workplace of the future. Academy of Management Perspectives, 12(3), 17-29.

Tran, M., Yang, Y., \& Raikundalia, G. (2004). Consumption of multiple concurrent identities: The need from the instant messaging virtual community. Australasian Journal of Information Systems, 11(2).

Van den Broeck, A., Schreurs, B., De Witte, H., Vansteenkiste, M., Germeys, F., \& Schaufeli, W. (2011). Understanding workaholics' motivations: A self-determination perspective. Applied Psychology, 60(4), 600-621.

Wilson, T. D. (2002). Alfred Schutz, phenomenology and research methodology for information behaviour research. The New Review of Information Behaviour Research, 3(71), $1-15$.

Yigitbasioglu, O. (2014). Modelling the intention to adopt cloud computing services: a transaction cost theory perspective. Australasian Journal of Information Systems, 18(3).

Zhang, S., Tremaine, M., Fjermestad, J., Milewski, A., \& O'Sullivan, P. (2006, October). Delegation in virtual team: The moderating effects of team maturity and team distance. In Global Software Engineering, 2006. ICGSE'06. International Conference on (pp. 62-68). IEEE. 


\section{Appendix 1}

\section{Representative Quotes (sic) underlying the Emic Interpretations.}

\begin{tabular}{|c|c|c|c|}
\hline S.No & Representative Quote & $\begin{array}{l}\text { Emic Theme } \\
\text { Interpretation }\end{array}$ & $\begin{array}{c}\text { Etic Theme } \\
\text { Mapping }\end{array}$ \\
\hline 1 & $\begin{array}{l}\text { So, we keep all the evidence mails and everything } \\
\text { for clarity of work process and for future } \\
\text { communication also. }\end{array}$ & Focus on Goal Clarity & $\begin{array}{l}\text { Communication } \\
\text { (formal) }\end{array}$ \\
\hline 2 & $\begin{array}{l}\text { I have been multi-tasking on different projects } \\
\text { parallels. But when it comes to priority, I have to do } \\
\text { one task on priority and send it to the customer or } \\
\text { other team or other subordinate once it is done. }\end{array}$ & Focus on Goal Clarity & $\begin{array}{l}\text { Communication } \\
\text { (formal) }\end{array}$ \\
\hline 3 & $\begin{array}{l}\text { Reporting involvement like the manager } \\
\text { involvement will be less if it is a virtual team. }\end{array}$ & Focus on Goal Clarity & $\begin{array}{l}\text { Communication } \\
\text { (formal) }\end{array}$ \\
\hline 4 & $\begin{array}{l}\text { If it is planned, the things go on fine. But if it is } \\
\text { unplanned, then there will be a problem. }\end{array}$ & Focus on Goal Clarity & $\begin{array}{l}\text { Communication } \\
\text { (formal) }\end{array}$ \\
\hline 5 & $\begin{array}{l}\text { Where ever the team is available, we will be able to } \\
\text { work well in such place. Because, there will be no } \\
\text { mental pressure, nothing will be there. We can able } \\
\text { to do it as soon as possible. Where the team is not } \\
\text { available, our concentration is only on the work, so } \\
\text { it is like, we will feel like somewhat stressed. }\end{array}$ & Focus on Goal Clarity & $\begin{array}{l}\text { Communication } \\
\text { (formal) }\end{array}$ \\
\hline 6 & $\begin{array}{l}\text { We properly define challenges and action plan every } \\
\text { week. And, every week we also have a meeting with } \\
\text { the senior management and update them about the } \\
\text { progress. So, no progress means I am sitting at } \\
\text { home! }\end{array}$ & Focus on Goal Clarity & $\begin{array}{l}\text { Communication } \\
\text { (formal) }\end{array}$ \\
\hline 7 & $\begin{array}{l}\text { As a manager, one has to ensure that the team is } \\
\text { working on a single goal. It becomes very important } \\
\text { while working in a virtual team. }\end{array}$ & Focus on Goal Clarity & $\begin{array}{l}\text { Communication } \\
\text { (formal) }\end{array}$ \\
\hline 8 & $\begin{array}{l}\text { There is conflict, but the problem in a GVT is more } \\
\text { difficult to identify. But, conflict does exist. And } \\
\text { when you get into conflict, personally, I have not } \\
\text { been successful in doing it while (sic) video } \\
\text { conference. You have to get together and sort it up. }\end{array}$ & Conflicts & $\begin{array}{l}\text { Communication } \\
\text { (informal) }\end{array}$ \\
\hline 9 & $\begin{array}{l}\text { A lot of times, when conflict gets into a GVT, that } \\
\text { becomes unproductive for work, one has to have a } \\
\text { face to face meeting with people in conflict and } \\
\text { resolve it. It is very difficult to resolve it in a virtual } \\
\text { environment. }\end{array}$ & Conflicts & $\begin{array}{l}\text { Communication } \\
\text { (informal) }\end{array}$ \\
\hline 10 & $\begin{array}{l}\text { Informal communication is very less. Everything we } \\
\text { follow is formal communication. }\end{array}$ & $\begin{array}{l}\text { Informal } \\
\text { Communication }\end{array}$ & $\begin{array}{l}\text { Communication } \\
\text { (informal) }\end{array}$ \\
\hline 11 & $\begin{array}{l}\text { Regular team meetings and team lunch that is } \\
\text { informal communication. }\end{array}$ & $\begin{array}{l}\text { Informal } \\
\text { Communication }\end{array}$ & $\begin{array}{l}\text { Communication } \\
\text { (informal) }\end{array}$ \\
\hline 12 & $\begin{array}{l}\text { Team building in a virtual team, like only on phone } \\
\text { communication or else the manager has to visit the } \\
\text { work office where his team is working, and or else } \\
\text { he has to talk on phone or regular, wishes on some } \\
\text { special days like birthdays, like we follow a general } \\
\text { practice where some of the team members is having } \\
\text { birthday we have celebrations. But in VT unless the } \\
\text { person visits here or there, then only it can be like. }\end{array}$ & $\begin{array}{l}\text { Informal } \\
\text { Communication }\end{array}$ & $\begin{array}{l}\text { Communication } \\
\text { (informal) }\end{array}$ \\
\hline
\end{tabular}




\begin{tabular}{|c|c|c|c|}
\hline S.No & Representative Quote & $\begin{array}{c}\text { Emic Theme } \\
\text { Interpretation }\end{array}$ & $\begin{array}{c}\text { Etic Theme } \\
\text { Mapping }\end{array}$ \\
\hline 13 & $\begin{array}{l}\text { Manager and team member communication is very } \\
\text { important thing. A recent scenario we have } \\
\text { implemented is, at least it is mandatory for him to } \\
\text { meet the team weekly once. Like apart from work I } \\
\text { am saying. Weekly once for team building apart } \\
\text { from work mandatory. so that if there are any } \\
\text { informal talks they can be discussed with the team } \\
\text { members on team lunch, team tea or team practices } \\
\text { or team outings. It will improve the interaction time } \\
\text { with the manager and it will also have a friendly } \\
\text { platform. }\end{array}$ & $\begin{array}{l}\text { Informal } \\
\text { Communication }\end{array}$ & $\begin{array}{l}\text { Communication } \\
\text { (informal) }\end{array}$ \\
\hline 14 & $\begin{array}{l}\text { Some people will be fine to explain everything with } \\
\text { call, but others might not be comfortable. So, in that } \\
\text { cases, we cannot communicate and it might not be } \\
\text { helpful. }\end{array}$ & $\begin{array}{l}\text { Informal } \\
\text { Communication }\end{array}$ & $\begin{array}{l}\text { Communication } \\
\text { (informal) }\end{array}$ \\
\hline 15 & $\begin{array}{l}\text { Only the communication will be different. } \\
\text { Whenever we want to communicate with people, } \\
\text { only that is the problem with virtual place. }\end{array}$ & $\begin{array}{l}\text { Informal } \\
\text { Communication }\end{array}$ & $\begin{array}{l}\text { Communication } \\
\text { (informal) }\end{array}$ \\
\hline 16 & $\begin{array}{l}\text { Interaction should be there and created by these } \\
\text { people. You cannot sit for long hours and work } \\
\text { without personal interaction. }\end{array}$ & $\begin{array}{l}\text { Informal } \\
\text { Communication }\end{array}$ & $\begin{array}{l}\text { Communication } \\
\text { (informal) }\end{array}$ \\
\hline 17 & $\begin{array}{l}\text { When an associate wants to explain the personal } \\
\text { reasons, then they feel that they cannot do it } \\
\text { through video or audio calls. If I see the person, that } \\
\text { will be definitely different, and if I am talking to the } \\
\text { face whom I know there is a difference with whom I } \\
\text { don't know. }\end{array}$ & $\begin{array}{l}\text { Informal } \\
\text { Communication }\end{array}$ & $\begin{array}{l}\text { Communication } \\
\text { (informal) }\end{array}$ \\
\hline 18 & $\begin{array}{l}\text { That difference has an impact on the work because it } \\
\text { will change your mood. So when you are refreshed, } \\
\text { you will have good productivity also. }\end{array}$ & $\begin{array}{l}\text { Informal } \\
\text { Communication }\end{array}$ & $\begin{array}{l}\text { Communication } \\
\text { (informal) }\end{array}$ \\
\hline 19 & $\begin{array}{l}\text { Only thing is that when we are isolated from the } \\
\text { organization, from the family, then there will be } \\
\text { personal sacrifices that you need to do. }\end{array}$ & $\begin{array}{l}\text { Informal } \\
\text { Communication }\end{array}$ & $\begin{array}{l}\text { Communication } \\
\text { (informal) }\end{array}$ \\
\hline 20 & $\begin{array}{l}\text { I think it is important for a team to understand and } \\
\text { also getting that additional information (through } \\
\text { informal communication) is always helpful. }\end{array}$ & $\begin{array}{l}\text { Informal } \\
\text { Communication }\end{array}$ & $\begin{array}{l}\text { Communication } \\
\text { (informal) }\end{array}$ \\
\hline 21 & $\begin{array}{l}\text { I think it is important for a team to understand and } \\
\text { also getting that additional information (through } \\
\text { informal communication) is always helpful. }\end{array}$ & $\begin{array}{l}\text { Informal } \\
\text { Communication }\end{array}$ & $\begin{array}{l}\text { Communication } \\
\text { (informal) }\end{array}$ \\
\hline 22 & $\begin{array}{l}\text { It's quite a different experience... It's like six months } \\
\text { we have been communicating this way and it's } \\
\text { really required. We are adapting to the situation. So, } \\
\text { now we are almost on the same lines. So, now there } \\
\text { is no problem with all this mails, conferences and } \\
\text { videos. }\end{array}$ & $\begin{array}{l}\text { Interpersonal } \\
\text { Relationships }\end{array}$ & $\begin{array}{l}\text { Communication } \\
\text { (informal) }\end{array}$ \\
\hline 23 & $\begin{array}{l}\text { Team building in a virtual team, like only on phone } \\
\text { communication or else the manager has to visit the } \\
\text { work office where his team is working, and or else } \\
\text { he has to talk on phone or regular, wishes on some } \\
\text { special days like birthdays, like we follow a general } \\
\text { practice where some of the team members is having } \\
\text { birthday we have celebrations. But in VT unless the } \\
\text { person visits here or there, then only it can be like. }\end{array}$ & $\begin{array}{l}\text { Interpersonal } \\
\text { Relationships }\end{array}$ & $\begin{array}{l}\text { Communication } \\
\text { (informal) }\end{array}$ \\
\hline
\end{tabular}




\begin{tabular}{|c|c|c|c|}
\hline S.No & Representative Quote & $\begin{array}{c}\text { Emic Theme } \\
\text { Interpretation }\end{array}$ & $\begin{array}{c}\text { Etic Theme } \\
\text { Mapping }\end{array}$ \\
\hline 24 & $\begin{array}{l}\text { But the person who is reporting them in a different } \\
\text { location his involvement will be less unless he visits } \\
\text { or they visit him. }\end{array}$ & $\begin{array}{l}\text { Interpersonal } \\
\text { Relationships }\end{array}$ & $\begin{array}{l}\text { Communication } \\
\text { (informal) }\end{array}$ \\
\hline 25 & $\begin{array}{l}\text { Some people will be fine to explain everything with } \\
\text { call, but others might not be comfortable. So, in that } \\
\text { cases, we cannot communicate and it might not be } \\
\text { helpful. }\end{array}$ & $\begin{array}{l}\text { Interpersonal } \\
\text { Relationships }\end{array}$ & $\begin{array}{l}\text { Communication } \\
\text { (informal) }\end{array}$ \\
\hline 26 & $\begin{array}{l}\text { We can find so many type of people at workplace, } \\
\text { everyone has their own attitudes, and some people } \\
\text { can be able to explain even a silly thing also without } \\
\text { hesitating and without any domination. So, we } \\
\text { cannot expect same thing from all people. }\end{array}$ & $\begin{array}{l}\text { Interpersonal } \\
\text { Relationships }\end{array}$ & $\begin{array}{l}\text { Communication } \\
\text { (informal) }\end{array}$ \\
\hline 27 & $\begin{array}{l}\text { Like in a collocated team, we have so many people } \\
\text { to interact here. So, obviously you may have to } \\
\text { spend some time to talk to others who ever are } \\
\text { sitting around you. So, that is the only one thing. }\end{array}$ & $\begin{array}{l}\text { Interpersonal } \\
\text { Relationships }\end{array}$ & $\begin{array}{l}\text { Communication } \\
\text { (informal) }\end{array}$ \\
\hline 28 & $\begin{array}{l}\text { Then obviously normal working place only. Because } \\
\text { we can interact with other people for some time if } \\
\text { you are not feeling well. Then at least you will get } \\
\text { some relaxation. }\end{array}$ & $\begin{array}{l}\text { Interpersonal } \\
\text { Relationships }\end{array}$ & $\begin{array}{l}\text { Communication } \\
\text { (informal) }\end{array}$ \\
\hline 29 & $\begin{array}{l}\text { But, you know, compared to talking to associates } \\
\text { and customers, there will be some difference. We } \\
\text { don't belong to that organization. }\end{array}$ & $\begin{array}{l}\text { Interpersonal } \\
\text { Relationships }\end{array}$ & $\begin{array}{l}\text { Communication } \\
\text { (informal) }\end{array}$ \\
\hline 30 & $\begin{array}{l}\text { In my experience after working for seven years, I } \\
\text { feel this small talk is a waste of time and somewhat } \\
\text { like spoils your mood also to work at place. It is not } \\
\text { always, because some people will talk very well } \\
\text { when they see you and some people will talk in } \\
\text { different way also. }\end{array}$ & $\begin{array}{l}\text { Interpersonal } \\
\text { Relationships }\end{array}$ & $\begin{array}{l}\text { Communication } \\
\text { (informal) }\end{array}$ \\
\hline 31 & $\begin{array}{l}\text { Like if you have seen the manager before, they will } \\
\text { come to know what kind of issues they can share } \\
\text { with the manager and cannot share with the } \\
\text { manager. Over technology you don't know how the } \\
\text { person might react. }\end{array}$ & $\begin{array}{l}\text { Interpersonal } \\
\text { Relationships }\end{array}$ & $\begin{array}{l}\text { Communication } \\
\text { (informal) }\end{array}$ \\
\hline 32 & $\begin{array}{l}\text { Our job depends on understanding. How the } \\
\text { manager and how I get through. So when your } \\
\text { reporting manager is face to face, this is what I say } \\
\text { him directly that this is the required problem and if } \\
\text { provided then it would be easy. So the direct } \\
\text { communication in terms of time there will be a } \\
\text { saving. }\end{array}$ & $\begin{array}{l}\text { Interpersonal } \\
\text { Relationships }\end{array}$ & $\begin{array}{l}\text { Communication } \\
\text { (informal) }\end{array}$ \\
\hline 33 & Yeah, it feels a bit isolated. & $\begin{array}{l}\text { Interpersonal } \\
\text { Relationships }\end{array}$ & $\begin{array}{l}\text { Communication } \\
\text { (informal) }\end{array}$ \\
\hline 34 & $\begin{array}{l}\text { You will not be able to see the organization } \\
\text { happenings, day to day events when you are } \\
\text { isolated. Ya, that seems to be bad. But again when } \\
\text { you are working in a project, you are a billable } \\
\text { resource, you will see that your compensation will } \\
\text { reach you. Your salary is there. Ya, so that's there. }\end{array}$ & $\begin{array}{l}\text { Interpersonal } \\
\text { Relationships }\end{array}$ & $\begin{array}{l}\text { Communication } \\
\text { (informal) }\end{array}$ \\
\hline
\end{tabular}




\begin{tabular}{|c|c|c|c|}
\hline S.No & Representative Quote & $\begin{array}{c}\text { Emic Theme } \\
\text { Interpretation }\end{array}$ & $\begin{array}{c}\text { Etic Theme } \\
\text { Mapping }\end{array}$ \\
\hline 35 & $\begin{array}{l}\text { One is you get to know each other when you form a } \\
\text { GVT and you are talking for the first time. Of } \\
\text { course, through formal communication, you get to } \\
\text { know each other, some of the details. But then } \\
\text { informal communication happens when you send } \\
\text { an email and you agree and put a small smiley. This } \\
\text { helps in building interpersonal relationships in a } \\
\text { virtual environment. }\end{array}$ & $\begin{array}{l}\text { Interpersonal } \\
\text { Relationships }\end{array}$ & $\begin{array}{l}\text { Communication } \\
\text { (informal) }\end{array}$ \\
\hline 36 & $\begin{array}{l}\text { If one has done their homework and understand } \\
\text { that there are circumstances and situations that } \\
\text { could be impacting the other person differently, } \\
\text { then, communication with the other person helps } \\
\text { build better interpersonal relationships with the } \\
\text { members who are geographically dispersed. This } \\
\text { will in a way allow to reduce the distance between } \\
\text { the locations }\end{array}$ & $\begin{array}{l}\text { Interpersonal } \\
\text { Relationships }\end{array}$ & $\begin{array}{l}\text { Communication } \\
\text { (informal) }\end{array}$ \\
\hline 37 & $\begin{array}{l}\text { There, the technical documents completely we read } \\
\text { and their local language Spanish, and we had a } \\
\text { challenge to convert them into English. And, we } \\
\text { have to learn Spanish in order to learn some } \\
\text { technical terminology. So, it was quite challenging } \\
\text { task for us. }\end{array}$ & Cultural Diversity & $\begin{array}{l}\text { Cultural } \\
\text { Intelligence }\end{array}$ \\
\hline 38 & $\begin{array}{l}\text { We had different people working for different } \\
\text { customers, Spain, UK, but the work is similar. But } \\
\text { the standards are different. Because, for Spain there } \\
\text { are different standards for work and UK there are } \\
\text { different standards. So, the work is similar but how } \\
\text { you are going to get the output done the procedure } \\
\text { is different. So I felt the platform like software that I } \\
\text { am using for Spain client is different from that of } \\
\text { UK. }\end{array}$ & Cultural Diversity & $\begin{array}{l}\text { Cultural } \\
\text { Intelligence }\end{array}$ \\
\hline 39 & $\begin{array}{l}\text { So I felt like there are different ways of getting the } \\
\text { output done for different clients and the other part is } \\
\text { in Spain also there are around } 13 \text { to } 14 \text { different } \\
\text { standards. So, it is also challenging that to change } \\
\text { from one task to another task, you have to go to } \\
\text { different standards. So you have to go back to the } \\
\text { technical documents and refresh everything before } \\
\text { starting the work. }\end{array}$ & Cultural Diversity & $\begin{array}{l}\text { Cultural } \\
\text { Intelligence }\end{array}$ \\
\hline
\end{tabular}




\begin{tabular}{|c|c|c|c|}
\hline S.No & Representative Quote & $\begin{array}{c}\text { Emic Theme } \\
\text { Interpretation }\end{array}$ & $\begin{array}{c}\text { Etic Theme } \\
\text { Mapping }\end{array}$ \\
\hline 40 & $\begin{array}{l}\text { There was one person who I worked with in } \\
\text { Germany, she was a fantastic contributor who had } \\
\text { taken significant responsibility and did that very } \\
\text { well. During one of the feedback sessions, when I } \\
\text { asked her what are the things we can do better and } \\
\text { how is she coming along, one thing that she said } \\
\text { was, during the initial days, she was actually } \\
\text { thinking of leaving the organisation, because she felt } \\
\text { so disrespected in the conference calls. She said that } \\
\text { "everybody is talking over me, and that is not } \\
\text { something that I am used to". And also said, if } \\
\text { somebody is talking, you finish that conversation, } \\
\text { you hear that person, and then you make a point, } \\
\text { and then the next person makes a point Right, she is } \\
\text { very used to that. She had not worked in a global } \\
\text { team before but she said that it took time for her to } \\
\text { understand that this is the way that people talk, (sic) } \\
\text { even though she could never understand the reason } \\
\text { behind it. }\end{array}$ & Cultural Diversity & $\begin{array}{l}\text { Cultural } \\
\text { Intelligence }\end{array}$ \\
\hline 41 & $\begin{array}{l}\text { The only thing I had to do was contact switching. By } \\
\text { contact switching what I mean is even though I am } \\
\text { speaking English, I speak in a different way, so they } \\
\text { understand. So this is what is contact switching. } \\
\text { And it works well. }\end{array}$ & Cultural Diversity & $\begin{array}{l}\text { Cultural } \\
\text { Intelligence }\end{array}$ \\
\hline 42 & $\begin{array}{l}\text { In such case we have used one platform, cisco to get } \\
\text { it solved, cisco like the desktop sharing option we } \\
\text { had, so we used to call the client on the video } \\
\text { conference, and using cisco, we used to get it solved. } \\
\text { That platform helped us to get things done easily } \\
\text { and in crucial times, when we had to meet some } \\
\text { deadlines without any change. }\end{array}$ & Coordination Issues & Technology \\
\hline 43 & $\begin{array}{l}\text { There will not be any problem when the teams are } \\
\text { located in different places, the only problem comes } \\
\text { how do you monitor the team members. because } \\
\text { work point of view everything is being live updated } \\
\text { on the server and the work status, everything is } \\
\text { updated on the server so, getting the things done by } \\
\text { people is the only thing you will be challenging, } \\
\text { apart from the work here there will not be any } \\
\text { problem when we are working in multiple locations } \\
\text { also. }\end{array}$ & Coordination Issues & Technology \\
\hline 44 & $\begin{array}{l}\text { We share them the task like this is the task for you, } \\
\text { and this is the task for you, but when the person will } \\
\text { come and get the take done, you don't know. Unless } \\
\text { and until either we call he or he calls us or we drop } \\
\text { us a text or he drops us a text. But, at what times he } \\
\text { might come and leave, we don't know. }\end{array}$ & Coordination Issues & Technology \\
\hline 45 & $\begin{array}{l}\text { I will tell you the same thing if at all a customer, if } \\
\text { we are sitting at a customer location in UK, like if } \\
\text { we have multiple queries, we segregate everything } \\
\text { and we will sit in front of the customer and the } \\
\text { things become easy. So, the amount of time taken to } \\
\text { solve the query is less when you are working in UK. }\end{array}$ & Coordination Issues & Technology \\
\hline
\end{tabular}




\begin{tabular}{|c|c|c|c|}
\hline S.No & Representative Quote & $\begin{array}{l}\text { Emic Theme } \\
\text { Interpretation }\end{array}$ & $\begin{array}{c}\text { Etic Theme } \\
\text { Mapping }\end{array}$ \\
\hline 46 & $\begin{array}{l}\text { But, when you are sitting in India, you consolidate } \\
\text { everything and you send an email to the customer, } \\
\text { call the customer on phone, some queries get solved } \\
\text { and sometimes the customer says that you have to } \\
\text { check back to his team members and get it done. So, } \\
\text { the response time is less there. }\end{array}$ & Coordination Issues & Technology \\
\hline 47 & $\begin{array}{l}\text { Until the designer does not complete his task I don't } \\
\text { have an input to the checker. So, the designer has to } \\
\text { close his task and only then the checker can have his } \\
\text { input. So, if this is delayed, the other person's work } \\
\text { will also be delayed. Entirely it will affect my } \\
\text { deadline. So, I have to closely monitor the person } \\
\text { sitting remotely to get the design part done. }\end{array}$ & Coordination Issues & Technology \\
\hline 48 & $\begin{array}{l}\text { For any change of policies we get an email } \\
\text { communication, like regularly HR was available at } \\
\text { floor, but if it is in remote location, unless and until } \\
\text { the employee goes with an issue, the HR cannot } \\
\text { respond in that. There is an issue, they will be } \\
\text { responding for sure. So it is up to the employee to } \\
\text { go and tell what the problem is then they will get } \\
\text { the response if it is in the remote location. }\end{array}$ & Coordination Issues & Technology \\
\hline 49 & $\begin{array}{l}\text { Like, when you take the UK time example, the team } \\
\text { sitting in UK working for some task, and the team } \\
\text { sitting in India with similar task, the time frame is } \\
\text { different, so there, the manager will be able to } \\
\text { monitor only for a partial time, either on phone, } \\
\text { email or any other communication. The other time } \\
\text { frame after office hours it will be difficult for the } \\
\text { manager and to contact the manager. }\end{array}$ & Coordination Issues & Technology \\
\hline 50 & $\begin{array}{l}\text { When it comes with the communication, it is about } \\
\text { the timings. That is something we cannot avoid. } \\
\text { Some things like if any activity has urgent delivery, } \\
\text { definitely there will be some time gap. If we have } \\
\text { sufficient time, there is no problem in communicate. } \\
\text { If some problems we cannot explain them email, we } \\
\text { can contact them by call or a video call. }\end{array}$ & Coordination Issues & Technology \\
\hline 51 & $\begin{array}{l}\text { I was one among the two people in UK, and four } \\
\text { people in Hyderabad. So, the manager was in } \\
\text { Hyderabad itself. So whenever we need changes, } \\
\text { then we request our employees from there only. So, } \\
\text { they were doing on time and the manager also } \\
\text { coordinates with them to deliver the work within } \\
\text { the time. We could able to manage well. Only the } \\
\text { problem comes whenever there is an urgency. }\end{array}$ & Coordination Issues & Technology \\
\hline 52 & $\begin{array}{l}\text { Because, in a virtual place, if we have any concerns } \\
\text { that we need to discuss with the manager, then we } \\
\text { will be able to explain to him easily, and work well } \\
\text { after that. When it comes to the technical matters } \\
\text { there are so many senior people available in a } \\
\text { normal set up. }\end{array}$ & Coordination Issues & Technology \\
\hline
\end{tabular}




\begin{tabular}{|c|c|c|c|}
\hline S.No & Representative Quote & $\begin{array}{c}\text { Emic Theme } \\
\text { Interpretation }\end{array}$ & $\begin{array}{c}\text { Etic Theme } \\
\text { Mapping }\end{array}$ \\
\hline 53 & $\begin{array}{l}\text { Where ever the team is available, we will be able to } \\
\text { work well in such place. Because, there will be no } \\
\text { mental pressure, nothing will be there. We can able } \\
\text { to do it as soon as possible. Where the team is not } \\
\text { available, our concentration is only on the work, so } \\
\text { it is like, we will feel like somewhat stressed. }\end{array}$ & Coordination Issues & Technology \\
\hline 54 & Getting the right inputs at the right time. & Coordination Issues & Technology \\
\hline 55 & $\begin{array}{l}\text { Because we can ask their opinion. We can directly } \\
\text { meet the experts available for the job. We can just do } \\
\text { better things. }\end{array}$ & Coordination Issues & Technology \\
\hline 56 & $\begin{array}{l}\text { GVTs face on-site and off-site issues. I was once } \\
\text { working from New York, and my team was in India. } \\
\text { Due to the change in time zones, we faced a lot of } \\
\text { difficulty in getting support from each other. And } \\
\text { when I was back in India, the process of follow-up } \\
\text { was also difficult. }\end{array}$ & Coordination Issues & Technology \\
\hline 57 & $\begin{array}{l}\text { Most of the members get involved 7/24 with the } \\
\text { team. Some of my team is in far-off Europe. It so } \\
\text { happens sometimes that they forget other team } \\
\text { members who are based out of their offices in their } \\
\text { emails. These situations reduce coordination within } \\
\text { the team. Some team members feel left out. So, out } \\
\text { of sight, out of mind situation often occurs in a GVT. }\end{array}$ & Coordination Issues & Technology \\
\hline 58 & $\begin{array}{l}\text { We share them the task like this is the task for you, } \\
\text { and this is the task for you, but when the person will } \\
\text { come and get the take done, you don't know. Unless } \\
\text { and until either we call he or he calls us or we drop } \\
\text { us a text or he drops us a text. But, at what times he } \\
\text { might come and leave, we don't know. }\end{array}$ & Spatial Distance & Technology \\
\hline 59 & $\begin{array}{l}\text { Everything it is comfortable when everyone is } \\
\text { located in the same location and it will be } \\
\text { challenging while meeting the targets like crucial } \\
\text { targets to control the people if they are at different } \\
\text { location. }\end{array}$ & Spatial Distance & Technology \\
\hline 60 & $\begin{array}{l}\text { Amount of dedication when we are in a virtual team } \\
\text { in different locations, we have to think more about } \\
\text { the person who is sitting in the remote areas, about } \\
\text { his task and when he can deliver his task, }\end{array}$ & Spatial Distance & Technology \\
\hline 61 & There are telecom where you need to have web-ex. & Technology Medium & Technology \\
\hline 62 & $\begin{array}{l}\text { the earlier team experience when we used on } \\
\text { software tools, which are completely out of scope, } \\
\text { the tool errors were completely out of our scope, we } \\
\text { have technical knowledge of how the system works, } \\
\text { like what we have to do, we used to take that } \\
\text { platform too, in order to do the testing, but the tool } \\
\text { error was completely out of our scope. }\end{array}$ & Technology Medium & Technology \\
\hline 63 & $\begin{array}{l}\text { In such case we have used one platform, cisco to get } \\
\text { it solved, cisco like the desktop sharing option we } \\
\text { had, so we used to call the client on the video } \\
\text { conference, and using cisco, we used to get it solved. } \\
\text { That platform helped us to get things done easily } \\
\text { and in crucial times, when we had to meet some } \\
\text { deadlines without any change. }\end{array}$ & Technology Medium & Technology \\
\hline
\end{tabular}




\begin{tabular}{|c|c|c|c|}
\hline S.No & Representative Quote & $\begin{array}{l}\text { Emic Theme } \\
\text { Interpretation }\end{array}$ & $\begin{array}{l}\text { Etic Theme } \\
\text { Mapping }\end{array}$ \\
\hline 64 & $\begin{array}{l}\text { If we have any queries or any challenges we } \\
\text { regularly we have telephonic conversation. So, as of } \\
\text { now what we are following is telephonic } \\
\text { conversation. And for any clarification we are } \\
\text { having RFI through email and technical queries, }\end{array}$ & Technology Medium & Technology \\
\hline 65 & $\begin{array}{l}\text { So, we keep all the evidence mails and everything } \\
\text { for that, and for future communication also. }\end{array}$ & Technology Medium & Technology \\
\hline 66 & $\begin{array}{l}\text { When the team is located in one location, coming to } \\
\text { the bottom level, like my team members, getting } \\
\text { work done it is easy. So, I directly report to my } \\
\text { manager on the status or else any updates through } \\
\text { email. Mostly I communicate with him over email. } \\
\text { So, I don't feel any challenge, due to remote location } \\
\text { or at my location. }\end{array}$ & Technology Medium & Technology \\
\hline 67 & $\begin{array}{l}\text { Like if you have seen the manager before, they will } \\
\text { come to know what kind of issues they can share } \\
\text { with the manager and cannot share with the } \\
\text { manager. Over technology you don't know how the } \\
\text { person might react. }\end{array}$ & Technology Medium & Technology \\
\hline 68 & $\begin{array}{l}\text { It's quite a different experience... it's like six months } \\
\text { we have been communicating this way and it's } \\
\text { really required. We are adapting to the situation. So, } \\
\text { now we are almost on the same lines. So, now there } \\
\text { is no problem with all this mails, conferences and } \\
\text { videos. }\end{array}$ & Technology Medium & Technology \\
\hline 69 & $\begin{array}{l}\text { So whenever a need arises, we will exchange our } \\
\text { interaction through mails, WebEx, phones as per the } \\
\text { requirement. }\end{array}$ & Technology Medium & Technology \\
\hline 70 & $\begin{array}{l}\text { Technology is an integral part of even having a } \\
\text { GVT. If you are not connected on a very regular } \\
\text { basis, GVTs cannot work. }\end{array}$ & Technology Medium & Technology \\
\hline 71 & $\begin{array}{l}\text { I think a lot of this has to depend on what I call the } \\
\text { virtual infrastructure. It is very important in a GVT } \\
\text { that you have the proper tools, means to connect to } \\
\text { the company, means to extract the data and put it } \\
\text { back, and means to talk to different people in your } \\
\text { team. }\end{array}$ & Technology Medium & Technology \\
\hline 72 & $\begin{array}{l}\text { Technology has also enabled us to reduce the } \\
\text { commuting through flights, back and forth etc. }\end{array}$ & Technology Medium & Technology \\
\hline 73 & $\begin{array}{l}\text { For us, and in UK, you might be knowing, they } \\
\text { work until late evening. For us at morning they } \\
\text { come at 12:00 or 1:00. So, we expect more mails in } \\
\text { the second half. And it also continues in the evening } \\
\text { hours. }\end{array}$ & Temporal Distance & Technology \\
\hline 74 & $\begin{array}{l}\text { But, when you are sitting in India, you consolidate } \\
\text { everything and you send an email to the customer, } \\
\text { call the customer on phone, some queries get solved } \\
\text { and sometimes the customer says that you have to } \\
\text { check back to his team members and get it done. So, } \\
\text { the response time is less there. }\end{array}$ & Temporal Distance & Technology \\
\hline
\end{tabular}




\begin{tabular}{|c|c|c|c|}
\hline S.No & Representative Quote & $\begin{array}{c}\text { Emic Theme } \\
\text { Interpretation }\end{array}$ & $\begin{array}{c}\text { Etic Theme } \\
\text { Mapping }\end{array}$ \\
\hline 75 & $\begin{array}{l}\text { Like, when you take the UK time example, the team } \\
\text { sitting in UK working for some task, and the team } \\
\text { sitting in India with similar task, the time frame is } \\
\text { different, so there, the manager will be able to } \\
\text { monitor only for a partial time, either on phone, } \\
\text { email or any other communication. The other time } \\
\text { frame after office hours it will be difficult for the } \\
\text { manager and to contact the manager. }\end{array}$ & Temporal Distance & Technology \\
\hline 76 & $\begin{array}{l}\text { When it comes with the communication, it is about } \\
\text { the timings. That is something we cannot avoid. } \\
\text { Some things like if any activity has urgent delivery, } \\
\text { definitely there will be some time gap. If we have } \\
\text { sufficient time, there is no problem in communicate. } \\
\text { If some problems we cannot explain them email, we } \\
\text { can contact them by call or a video call. }\end{array}$ & Temporal Distance & Technology \\
\hline 77 & $\begin{array}{l}\text { But where the deliveries are a project need an } \\
\text { immediate output and the schedule is so tight, so in } \\
\text { that instances we can go with direct meetings or } \\
\text { putting a report. It depends on the type of work you } \\
\text { are in. }\end{array}$ & Temporal Distance & Technology \\
\hline 78 & $\begin{array}{l}\text { It sometimes happens that team members located } \\
\text { outside of the headquarters, or outside of the } \\
\text { location wherever the leader is located is, there is a } \\
\text { tendency for teams who are in one location to just } \\
\text { start brainstorming an idea, come up with } \\
\text { something, some sort of a draft etc., and then go to a } \\
\text { GVT or teams outside of that headquarter or teams } \\
\text { outside of that geography and ask them for their } \\
\text { feedback. The teams which are (sic), they don't see } \\
\text { anything wrong in that, we are soliciting inputs, we } \\
\text { are making this part, but the problems with (sic) the } \\
\text { teams outside see is that we want to be in the } \\
\text { brainstorming meeting. }\end{array}$ & Temporal Distance & Technology \\
\hline 79 & $\begin{array}{l}\text { Dedication depends on individual responsibility. If } \\
\text { he feels responsible and thinks that he is the one to } \\
\text { get the task done, so you can get it done in limited } \\
\text { time frame or you can also take extra amount of } \\
\text { time. But, when he is at a different location and not } \\
\text { taking ownership, it is always difficult to trace him } \\
\text { even though they are calling him and he has any } \\
\text { technical competency in that particular task which is } \\
\text { lesser where we might have to mentor him, and give } \\
\text { some support, then it will be a difficult task. }\end{array}$ & $\begin{array}{l}\text { Team Member } \\
\text { Maturity }\end{array}$ & $\begin{array}{l}\text { Trust \& Maturity } \\
\text { (separated) }\end{array}$ \\
\hline 80 & $\begin{array}{l}\text { Because the amount of experience which he } \\
\text { (experienced employee) has, is already high and he } \\
\text { has to be ready to accept any kind of task for any } \\
\text { kind of customer. His experience speaks, not } \\
\text { anything. }\end{array}$ & $\begin{array}{l}\text { Team Member } \\
\text { Maturity }\end{array}$ & $\begin{array}{l}\text { Trust \& Maturity } \\
\text { (separated) }\end{array}$ \\
\hline 81 & $\begin{array}{l}\text { I don't think so, because every individual as an } \\
\text { employee has to take the ownership for his task and } \\
\text { he has to definitely come back when the task is done } \\
\text { to get the second task. So, ownership is the first } \\
\text { quality where every individual has to own in a } \\
\text { company. }\end{array}$ & $\begin{array}{l}\text { Team Member } \\
\text { Maturity }\end{array}$ & $\begin{array}{l}\text { Trust \& Maturity } \\
\text { (separated) }\end{array}$ \\
\hline
\end{tabular}




\begin{tabular}{|c|c|c|c|}
\hline S.No & Representative Quote & $\begin{array}{c}\text { Emic Theme } \\
\text { Interpretation }\end{array}$ & $\begin{array}{l}\text { Etic Theme } \\
\text { Mapping }\end{array}$ \\
\hline 82 & $\begin{array}{l}\text { The basic thing that differs is that in a normal team, } \\
\text { employee as I told you feels less responsible because } \\
\text { there is some person who is monitoring him. But in } \\
\text { a virtual team, there has to be completely full fledge } \\
100 \% \text { responsible for the task which is in hand, } \\
\text { because it is being less monitored. }\end{array}$ & $\begin{array}{l}\text { Team Member } \\
\text { Maturity }\end{array}$ & $\begin{array}{l}\text { Trust \& Maturity } \\
\text { (separated) }\end{array}$ \\
\hline 83 & $\begin{array}{l}\text { Reporting involvement like the manager } \\
\text { involvement will be less if it is a virtual team. }\end{array}$ & $\begin{array}{l}\text { Team Member } \\
\text { Maturity }\end{array}$ & $\begin{array}{l}\text { Trust \& Maturity } \\
\text { (separated) }\end{array}$ \\
\hline 84 & $\begin{array}{l}\text { I was in UK last year and at that time, myself and } \\
\text { one of my colleague, both was in UK. My manager } \\
\text { was in Hyderabad office. That time we came to } \\
\text { know how to deal with the client and how to talk to } \\
\text { them in case of official way, or whatever we need. }\end{array}$ & $\begin{array}{l}\text { Team Member } \\
\text { Maturity }\end{array}$ & $\begin{array}{l}\text { Trust \& Maturity } \\
\text { (separated) }\end{array}$ \\
\hline 85 & $\begin{array}{l}\text { In a virtual team, you need not waste much time } \\
\text { talking to other people. It is a human tendency if we } \\
\text { have surroundings, sometimes we try to talk to } \\
\text { them, not always. If you are in virtual place, you } \\
\text { don't have chance to speak to so many people. So, } \\
\text { obviously you can do your work faster. }\end{array}$ & $\begin{array}{l}\text { Team Member } \\
\text { Maturity }\end{array}$ & $\begin{array}{l}\text { Trust \& Maturity } \\
\text { (separated) }\end{array}$ \\
\hline 86 & $\begin{array}{l}\text { Suppose if you take me and the company is not } \\
\text { monitoring me, I will do my job and what are all the } \\
\text { necessary things to complete the project. Some } \\
\text { people, unless manager comes to them and tells } \\
\text { them, they won't react to the work or timings and } \\
\text { all. }\end{array}$ & $\begin{array}{l}\text { Team Member } \\
\text { Maturity }\end{array}$ & $\begin{array}{l}\text { Trust \& Maturity } \\
\text { (separated) }\end{array}$ \\
\hline 87 & $\begin{array}{l}\text { Some people who are like they want to come late to } \\
\text { office and go early from office, those type of people } \\
\text { cannot be kept in a virtual team. }\end{array}$ & $\begin{array}{l}\text { Team Member } \\
\text { Maturity }\end{array}$ & $\begin{array}{l}\text { Trust \& Maturity } \\
\text { (separated) }\end{array}$ \\
\hline 88 & $\begin{array}{l}\text { It's like you feel very determined. It's kind of job } \\
\text { responsibility. It's like given my consent to the } \\
\text { organization but I will be doing these roles } \\
\text { whenever necessary. So I feel like it's my job } \\
\text { responsibility. }\end{array}$ & $\begin{array}{l}\text { Team Member } \\
\text { Maturity }\end{array}$ & $\begin{array}{l}\text { Trust \& Maturity } \\
\text { (separated) }\end{array}$ \\
\hline 89 & $\begin{array}{l}\text { You will not be able to see the organization } \\
\text { happenings, day to day events when you are } \\
\text { isolated. Ya, that seems to be bad. But again when } \\
\text { you are working in a project, you are a billable } \\
\text { resource, you will see that your compensation will } \\
\text { reach you. Your salary is there. Ya, so that's there. }\end{array}$ & $\begin{array}{l}\text { Team Member } \\
\text { Maturity }\end{array}$ & $\begin{array}{l}\text { Trust \& Maturity } \\
\text { (separated) }\end{array}$ \\
\hline 90 & $\begin{array}{l}\text { They should have the skills, the fitting in, writing e- } \\
\text { mails, basic corporate skill, then the people doing it, } \\
\text { it should be easy for them to interact with such kind } \\
\text { of people. }\end{array}$ & $\begin{array}{l}\text { Team Member } \\
\text { Maturity }\end{array}$ & $\begin{array}{l}\text { Trust \& Maturity } \\
\text { (separated) }\end{array}$ \\
\hline 91 & $\begin{array}{l}\text { Mentoring will give him confidence. He should be } \\
\text { under guidance. }\end{array}$ & $\begin{array}{l}\text { Team Member } \\
\text { Maturity }\end{array}$ & $\begin{array}{l}\text { Trust \& Maturity } \\
\text { (separated) }\end{array}$ \\
\hline 92 & $\begin{array}{l}\text { Because they are away from the team, they will } \\
\text { come to know what are all the things they have to } \\
\text { do on their own. So, if they want to do something, } \\
\text { no one will be there to guide them and they will face } \\
\text { the situation on how to do it. And they will come to } \\
\text { know on their own. }\end{array}$ & $\begin{array}{l}\text { Team Member Trust } \\
\text { and Maturity }\end{array}$ & $\begin{array}{l}\text { Trust \& Maturity } \\
\text { (separated) }\end{array}$ \\
\hline 93 & $\begin{array}{l}\text { The relationships are built only on trust. Everyone } \\
\text { wants to be a part of a winning story. Due to spatial } \\
\text { dispersion, a lot of communication can go wrong } \\
\text { due to lack of trust. }\end{array}$ & $\begin{array}{l}\text { Team Member Trust } \\
\text { and Maturity }\end{array}$ & $\begin{array}{l}\text { Trust \& Maturity } \\
\text { (separated) }\end{array}$ \\
\hline
\end{tabular}




\begin{tabular}{|c|l|l|l|}
\hline S.No & \multicolumn{1}{|c|}{ Representative Quote } & \multicolumn{1}{|c|}{$\begin{array}{c}\text { Emic Theme } \\
\text { Interpretation }\end{array}$} & $\begin{array}{c}\text { Etic Theme } \\
\text { Mapping }\end{array}$ \\
\hline 94 & $\begin{array}{l}\text { There are some people who will find it difficult to } \\
\text { work in a GVT because here at the end of the day } \\
\text { you are not answerable to your manager, you are } \\
\text { answerable to the goals, and you are answerable to } \\
\text { the outputs that you have to come up with. }\end{array}$ & $\begin{array}{l}\text { Team Member Trust } \\
\text { and Maturity }\end{array}$ & $\begin{array}{l}\text { Trust \& Maturity } \\
\text { (separated) }\end{array}$ \\
\hline 95 & $\begin{array}{l}\text { Then obviously normal working place only. Because } \\
\text { we can interact with other people for some time if } \\
\text { you are not feeling well. Then at least you will get } \\
\text { some relaxation. }\end{array}$ & Trust & $\begin{array}{l}\text { Trust \& Maturity } \\
\text { (separated) }\end{array}$ \\
\hline 96 & $\begin{array}{l}\text { But, you know, compared to talking to associates } \\
\text { and customers, there will be some difference. We } \\
\text { don't belong to that organization. }\end{array}$ & Trust & $\begin{array}{l}\text { Trust \& Maturity } \\
\text { (separated) }\end{array}$ \\
\hline
\end{tabular}




\section{Appendix II}

Data Structure - First Order Dimensions, Second Order Themes, Emic and Etic Theme

\section{Mapping}

\begin{tabular}{|c|c|c|c|c|}
\hline $\begin{array}{l}\text { S. } \\
\text { No. }\end{array}$ & First Order Dimensions & $\begin{array}{l}\text { Second Order } \\
\text { Theme }\end{array}$ & Emic Theme & $\begin{array}{l}\text { Etic } \\
\text { Theme }\end{array}$ \\
\hline 1 & \multirow{6}{*}{$\begin{array}{l}\text { personality, work requirement goals, how they } \\
\text { operate, style of working is diff for diff team } \\
\text { members } \\
\text { sensitivity/sentiment - body language, how serious } \\
\text { the customers are, have to judge through a con call } \\
\text { spend time and more effort to understand } \\
\text { personality } \\
\text { understanding individual personality } \\
\text { use different tactics with different people depending } \\
\text { on the feasible context } \\
\text { make adjustment comfortable to the other person }\end{array}$} & \multirow{6}{*}{$\begin{array}{l}\text { Understanding } \\
\text { Personality }\end{array}$} & \multirow{6}{*}{$\begin{array}{l}\text { Improved Trust } \\
\text { by } \\
\text { understanding } \\
\text { personality }\end{array}$} & \multirow{16}{*}{ 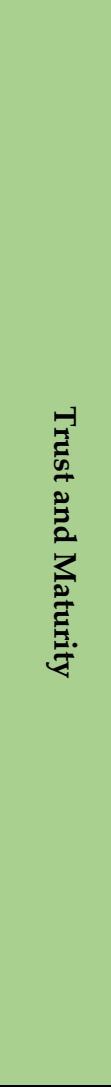 } \\
\hline 2 & & & & \\
\hline 3 & & & & \\
\hline 4 & & & & \\
\hline 5 & & & & \\
\hline 6 & & & & \\
\hline 7 & \multirow{7}{*}{$\begin{array}{l}\text { handling differing perceptions } \\
\text { GVTs-perceptions management } \\
\text { don't know how the other person will react } \\
\text { how sender sends the message and receiver } \\
\text { perceives it } \\
\text { different means are comfortable for different people } \\
\text { power relations are underplayed in GVTs } \\
\text { expert power and distributed leadership }\end{array}$} & \multirow{7}{*}{$\begin{array}{l}\text { Perception } \\
\text { Management and } \\
\text { Power Relations }\end{array}$} & \multirow{7}{*}{$\begin{array}{l}\text { Managing } \\
\text { perceptions to } \\
\text { improve trust }\end{array}$} & \\
\hline 8 & & & & \\
\hline 9 & & & & \\
\hline 10 & & & & \\
\hline 11 & & & & \\
\hline 12 & & & & \\
\hline 13 & & & & \\
\hline 14 & \multirow{3}{*}{$\begin{array}{l}\text { need a mature team, self-managed, people should } \\
\text { take initiatives to deliver } \\
\text { need more mature people who take responsibility } \\
\text { high level of motivation to instinctively take } \\
\text { ownership }\end{array}$} & \multirow{3}{*}{ Team Maturity } & \multirow{3}{*}{$\begin{array}{l}\text { Team Member } \\
\text { Maturity }\end{array}$} & \\
\hline 15 & & & & \\
\hline 16 & & & & \\
\hline
\end{tabular}




\begin{tabular}{|c|c|c|c|c|}
\hline $\begin{array}{l}\text { S. } \\
\text { No. }\end{array}$ & First Order Dimensions & $\begin{array}{l}\text { Second Order } \\
\text { Theme }\end{array}$ & Emic Theme & $\begin{array}{l}\text { Etic } \\
\text { Theme }\end{array}$ \\
\hline 17 & \multirow{10}{*}{$\begin{array}{l}\text { GVTs - skills needed are adaptation, email, } \\
\text { communication made easy team members } \\
\text { writing mail will give limited and restricted } \\
\text { communication, } \\
\text { informal communication opportunities are less } \\
\text { GVTs - team members interact limited time } \\
\text { expression of emotions and feelings not possible in } \\
\text { GVTs } \\
\text { informal communication difficult in GVTs } \\
\text { human interactions are reduced } \\
\text { difference between explanation and understanding } \\
\text { informal communication - raise questions outside } \\
\text { work, updates, informal chats } \\
\text { GVTs -not many people for suggestions, few people } \\
\text { around to ask }\end{array}$} & \multirow{10}{*}{$\begin{array}{l}\text { Skills needed } \\
\text { and Challenges } \\
\text { for } \\
\text { communication }\end{array}$} & \multirow{10}{*}{$\begin{array}{l}\text { Communication } \\
\text { Skills }\end{array}$} & \multirow{34}{*}{ 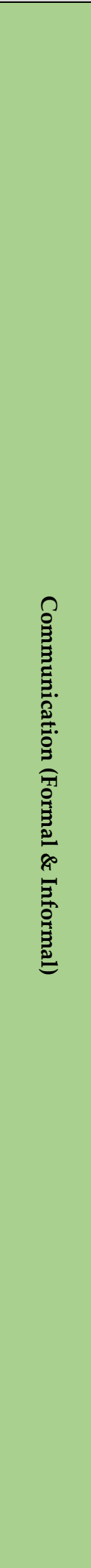 } \\
\hline 18 & & & & \\
\hline 19 & & & & \\
\hline 20 & & & & \\
\hline 21 & & & & \\
\hline 22 & & & & \\
\hline 23 & & & & \\
\hline 24 & & & & \\
\hline 25 & & & & \\
\hline 26 & & & & \\
\hline 27 & \multirow{13}{*}{$\begin{array}{l}\text { The need to socialize does not get fulfilled. Social } \\
\text { needs not getting fulfilled by working remotely. } \\
\text { less social get-togethers, not refreshed and not set to } \\
\text { right mood } \\
\text { GVTs - feel isolated, miss out on local events } \\
\text { GVTs - social needs do not get satisfied } \\
\text { need for belongingness not satisfied } \\
\text { people who need face time and need to talk to their } \\
\text { managers face difficulty } \\
\text { informal meets like lunch, discussion, going out etc. } \\
\text { missing } \\
\text { no people around you to share your problems } \\
\text { GVTs- positive energy from team members is } \\
\text { missing } \\
\text { GVTs- cant share if you are not well, collocated } \\
\text { team you can } \\
\text { GVTs - personal issues cannot be discussed } \\
\text { more emotional exhaustion than physical } \\
\text { GVTs - less experience in emotion, less appreciation } \\
\text { of human experiences, }\end{array}$} & \multirow{13}{*}{$\begin{array}{l}\text { Unfulfilled } \\
\text { social needs }\end{array}$} & \multirow{20}{*}{$\begin{array}{l}\text { Interpersonal } \\
\text { Relationships }\end{array}$} & \\
\hline 28 & & & & \\
\hline 29 & & & & \\
\hline 30 & & & & \\
\hline 31 & & & & \\
\hline 32 & & & & \\
\hline 33 & & & & \\
\hline 34 & & & & \\
\hline 35 & & & & \\
\hline 36 & & & & \\
\hline 37 & & & & \\
\hline 38 & & & & \\
\hline 39 & & & & \\
\hline 40 & \multirow{7}{*}{$\begin{array}{l}\text { GVTs - no one to chase you or help you } \\
\text { All forms of communication important in GVTs } \\
\text { extend feelings to care about family, social media, } \\
\text { birthday, small things for bonding } \\
\text { GVTs - skype, VC, WhatsApp, non-visual } \\
\text { communication } \\
\text { interaction deliberation } \\
\text { contribution to a purpose, then collaborate, } \\
\text { communicate and support } \\
\text { sense of appreciation is less, and feel uncomfortable } \\
\text { even when performing well }\end{array}$} & \multirow{7}{*}{$\begin{array}{l}\text { Implications for } \\
\text { Managers }\end{array}$} & & \\
\hline 41 & & & & \\
\hline 42 & & & & \\
\hline 43 & & & & \\
\hline 44 & & & & \\
\hline 45 & & & & \\
\hline 46 & & & & \\
\hline 47 & \multirow{4}{*}{$\begin{array}{l}\text { manage conflict in GVTs } \\
\text { resolving conflicts } \\
\text { conflict management is high } \\
\text { conflict not so visible, hidden and be brewing inside }\end{array}$} & \multirow{4}{*}{ Conflicts } & \multirow{4}{*}{$\begin{array}{l}\text { Conflict } \\
\text { Management }\end{array}$} & \\
\hline 48 & & & & \\
\hline 49 & & & & \\
\hline 50 & & & & \\
\hline
\end{tabular}




\begin{tabular}{|c|c|c|c|c|}
\hline $\begin{array}{c}\text { S. } \\
\text { No. }\end{array}$ & First Order Dimensions & $\begin{array}{c}\text { Second Order } \\
\text { Theme }\end{array}$ & Emic Theme & $\begin{array}{l}\text { Etic } \\
\text { Theme }\end{array}$ \\
\hline 51 & \multirow{23}{*}{$\begin{array}{l}\text { Tasks specified - disjunctive and conjunctive tasks } \\
\text { conjunctive - need to build on opinion/inputs of } \\
\text { other members on projects } \\
\text { GVTs - clear KPIs objectives and goals } \\
\text { need for clear, crisp and adjectives } \\
\text { conscious efforts, structured way of putting it to all } \\
\text { stakeholders } \\
\text { structured, weekly biweekly call, updates and } \\
\text { dedicated time } \\
\text { GVTs meetings-structured pointed and formal } \\
\text { use regular meetings, frequency } \\
\text { lot of groundwork before meeting } \\
\text { GVTs-employees not answerable to managers but to } \\
\text { goals and objectives } \\
\text { set expectations right, set frequency meeting } \\
\text { role of manager to set clear goals and aims } \\
\text { how do team members get to work and how they } \\
\text { achieve it } \\
\text { clear with goal } \\
\text { setting/expectations/parameters/guidelines } \\
\text { setting expectations right } \\
\text { clean and correct messaging for each stakeholder } \\
\text { timely work reduces challenges } \\
\text { setting expectations right } \\
\text { make team members accountable } \\
\text { set objective and make people understand it, check } \\
\text { output } \\
\text { once, twice in a month meeting will be with all team } \\
\text { members, less frequent contact } \\
\text { discipline and be responsive and prompt } \\
\text { take responsibility of your decision }\end{array}$} & \multirow{23}{*}{$\begin{array}{l}\text { Task } \\
\text { Structure/Goal } \\
\text { Clarity }\end{array}$} & \multirow{23}{*}{$\begin{array}{l}\text { Focus on Goal } \\
\text { Clarity }\end{array}$} & \multirow{23}{*}{ 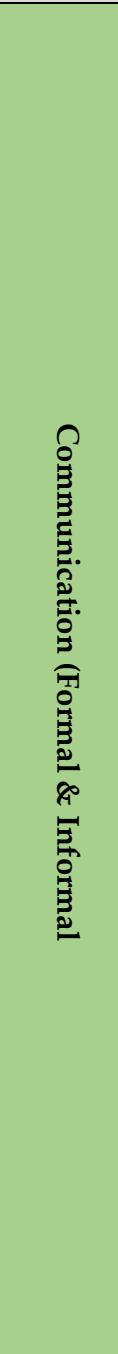 } \\
\hline 52 & & & & \\
\hline 53 & & & & \\
\hline 54 & & & & \\
\hline 55 & & & & \\
\hline 56 & & & & \\
\hline 57 & & & & \\
\hline 58 & & & & \\
\hline 59 & & & & \\
\hline 60 & & & & \\
\hline 61 & & & & \\
\hline 62 & & & & \\
\hline 63 & & & & \\
\hline 64 & & & & \\
\hline 65 & & & & \\
\hline 66 & & & & \\
\hline 67 & & & & \\
\hline 68 & & & & \\
\hline 69 & & & & \\
\hline 70 & & & & \\
\hline 71 & & & & \\
\hline 72 & & & & \\
\hline 73 & & & & \\
\hline
\end{tabular}




\begin{tabular}{|c|c|c|c|c|}
\hline $\begin{array}{l}\text { S. } \\
\text { No. }\end{array}$ & First Order Dimensions & $\begin{array}{c}\text { Second Order } \\
\text { Theme }\end{array}$ & Emic Theme & $\begin{array}{l}\text { Etic } \\
\text { Theme }\end{array}$ \\
\hline 74 & \multirow{8}{*}{$\begin{array}{l}\text { technology as a tool to collaborate and progress, } \\
\text { enabler, stay connected } \\
\text { technology - enable GVTs online chats, discussions } \\
\text { etc. } \\
\text { Technology is enabler. Technology selection plays } \\
\text { role. } \\
\text { GVTs-thrive on technology and flexibility } \\
\text { enjoy technology connections } \\
\text { millennials comfortable with technology, non-visual } \\
\text { and non-verbal communication } \\
\text { use of technology } \\
\text { new technology advancement }\end{array}$} & \multirow{8}{*}{$\begin{array}{l}\text { Technology as } \\
\text { enabler }\end{array}$} & \multirow{23}{*}{$\begin{array}{l}\text { Coordination } \\
\text { Issues, Temporal } \\
\text { and Spatial } \\
\text { Distance }\end{array}$} & \multirow{35}{*}{ 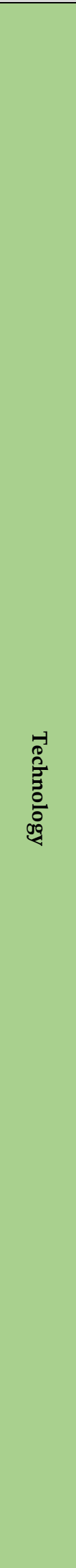 } \\
\hline 75 & & & & \\
\hline 76 & & & & \\
\hline 77 & & & & \\
\hline 78 & & & & \\
\hline 79 & & & & \\
\hline 80 & & & & \\
\hline 81 & & & & \\
\hline 82 & \multirow{7}{*}{$\begin{array}{l}\text { GVTs possible to hide info } \\
\text { when network is down, it is a problem } \\
\text { Delay in addressing challenges } \\
\text { can't take up unplanned actions in vt } \\
\text { technology - weak network in certain areas, big size } \\
\text { file problem } \\
\text { GVTs - communication through technology, hide } \\
\text { behind the email/text messages } \\
\text { in isolation - disjunctive - no inputs, lag/delay, not } \\
\text { so much now due to advanced technology }\end{array}$} & \multirow{7}{*}{$\begin{array}{l}\text { Technology as } \\
\text { Deterrent }\end{array}$} & & \\
\hline 83 & & & & \\
\hline 84 & & & & \\
\hline 85 & & & & \\
\hline 86 & & & & \\
\hline 87 & & & & \\
\hline 88 & & & & \\
\hline 89 & \multirow{8}{*}{$\begin{array}{l}\text { most interaction on VC, Skype, phone and less } \\
\text { frequent visit } \\
\text { Means of communication - email, calls, WebEx } \\
\text { Virtual infrastructure important, tools to connect, } \\
\text { extract and tell different people in the team } \\
\text { Depending on the type of task, technology is used. } \\
\text { GVTs-interpersonal mechanism is email } \\
\text { tech advancement - positive for GVTs, reduces cost, } \\
\text { VC, Skype etc. increase interaction } \\
\text { Different medium } \\
\text { GVTs- most connection through email }\end{array}$} & \multirow{8}{*}{$\begin{array}{l}\text { Virtual } \\
\text { Infrastructure }\end{array}$} & & \\
\hline 90 & & & & \\
\hline 91 & & & & \\
\hline 92 & & & & \\
\hline 93 & & & & \\
\hline 94 & & & & \\
\hline 95 & & & & \\
\hline 96 & & & & \\
\hline 97 & \multirow{12}{*}{$\begin{array}{l}\text { GVTs-need extra time and efforts to connect, bond } \\
\text { and understand } \\
\text { building relations through technology } \\
\text { GVTs can't see body language so use Skype and VC } \\
\text { On phone talk and open up for things you can't } \\
\text { write on email. } \\
\text { GVTs - technology bad link, lag in responding, } \\
\text { language misinterpretation } \\
\text { engagement is high if they are happy working over } \\
\text { technology } \\
\text { GVTs connection becomes a priority and } \\
\text { responsibility } \\
\text { use technology that the other person is comfortable } \\
\text { with } \\
\text { set clear expectations and tasks, use technology to } \\
\text { share info and empower people } \\
\text { customize + localize (tech, people process) } \\
\text { establishing connect through emails } \\
\text { millennials comfortable with emotions in } \\
\text { technology but not bosses }\end{array}$} & \multirow{12}{*}{$\begin{array}{l}\text { Efforts towards } \\
\text { connecting at } \\
\text { personal level }\end{array}$} & \multirow{12}{*}{$\begin{array}{l}\text { Coordination } \\
\text { Issues }\end{array}$} & \\
\hline 98 & & & & \\
\hline 99 & & & & \\
\hline 100 & & & & \\
\hline 101 & & & & \\
\hline 102 & & & & \\
\hline 103 & & & & \\
\hline 104 & & & & \\
\hline 105 & & & & \\
\hline 106 & & & & \\
\hline 107 & & & & \\
\hline 108 & & & & \\
\hline
\end{tabular}




\begin{tabular}{|c|c|c|c|c|}
\hline $\begin{array}{l}\text { S. } \\
\text { No. }\end{array}$ & First Order Dimensions & $\begin{array}{c}\text { Second Order } \\
\text { Theme }\end{array}$ & Emic Theme & $\begin{array}{l}\text { Etic } \\
\text { Theme }\end{array}$ \\
\hline 109 & \multirow{5}{*}{$\begin{array}{l}\text { no time lag, round the clock connection irrespective } \\
\text { of time zone } \\
\text { time zone diff - incorporate flexibility } \\
\text { time gap to get issues solved } \\
\text { same time zone, not much frustration (0-3 hours) } \\
\text { can initiate calls } \\
\text { time zone flexibility }\end{array}$} & \multirow{5}{*}{$\begin{array}{l}\text { Advantage of } \\
\text { Time zone } \\
\text { differences }\end{array}$} & \multirow{21}{*}{$\begin{array}{l}\text { Temporal/Spatial } \\
\text { Distance }\end{array}$} & \multirow{21}{*}{ 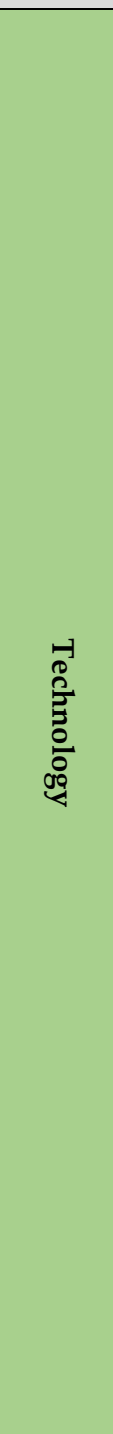 } \\
\hline 110 & & & & \\
\hline 111 & & & & \\
\hline 112 & & & & \\
\hline 113 & & & & \\
\hline 114 & \multirow{5}{*}{$\begin{array}{l}\text { VT Coordination Challenges } \\
\text { set fixed meeting times } \\
\text { coordination issue to find appropriate time } \\
\text { more time on collaborating to set meeting } \\
\text { Time zone differences, managing meetings }\end{array}$} & \multirow{5}{*}{$\begin{array}{l}\text { Coordination } \\
\text { according to the } \\
\text { Time Zone }\end{array}$} & & \\
\hline 115 & & & & \\
\hline 116 & & & & \\
\hline 117 & & & & \\
\hline 118 & & & & \\
\hline 119 & \multirow{5}{*}{$\begin{array}{l}\text { more challenging when you have to meet deadlines } \\
\text { - time zone matters } \\
\text { GVTs-process affected by time zones } \\
\text { high time zone difference, more frustration, need } \\
\text { more adjustment } \\
\text { time zone differences } \\
\text { information and use of emoticons, skype chat, } \\
\text { sensitive to time zones, lunch time }\end{array}$} & \multirow{5}{*}{$\begin{array}{l}\text { Challenges due } \\
\text { to Time Zone }\end{array}$} & & \\
\hline 120 & & & & \\
\hline 121 & & & & \\
\hline 122 & & & & \\
\hline 123 & & & & \\
\hline 124 & \multirow{6}{*}{$\begin{array}{l}\text { can't respond quickly to issues } \\
\text { time zone challenges - some decisions cannot wait } \\
\text { for sleeping people, but they have valuable inputs } \\
\text { for decisions } \\
\text { problem of getting right input at right time } \\
\text { time differences, long time taking, quick feedback } \\
\text { not possible, allow delay or not take input of some } \\
\text { people } \\
\text { time zone - time gap is the bridge, issues in } \\
\text { coordination } \\
\text { response to email - introducing people, syncing } \\
\text { calendars, time, difficult to involve all in } \\
\text { brainstorming }\end{array}$} & \multirow{6}{*}{$\begin{array}{l}\text { Response time } \\
\text { due to Time } \\
\text { Zone }\end{array}$} & & \\
\hline 125 & & & & \\
\hline 126 & & & & \\
\hline 127 & & & & \\
\hline 128 & & & & \\
\hline 129 & & & & \\
\hline
\end{tabular}




\begin{tabular}{|c|c|c|c|c|}
\hline $\begin{array}{l}\text { S. } \\
\text { No. }\end{array}$ & First Order Dimensions & $\begin{array}{c}\text { Second Order } \\
\text { Theme }\end{array}$ & Emic Theme & $\begin{array}{l}\text { Etic } \\
\text { Theme }\end{array}$ \\
\hline 130 & \multirow{4}{*}{$\begin{array}{l}\text { driving change is challenging in cross cultural env } \\
\text { train and plant people in different geographies } \\
\text { change in mindset } \\
\text { uniqueness and uniformity of org culture spreads } \\
\text { across locations }\end{array}$} & \multirow{13}{*}{$\begin{array}{l}\text { Cross Cultural } \\
\text { Environment }\end{array}$} & \multirow{4}{*}{$\begin{array}{l}\text { Cultural } \\
\text { Diversity }\end{array}$} & \multirow{23}{*}{ 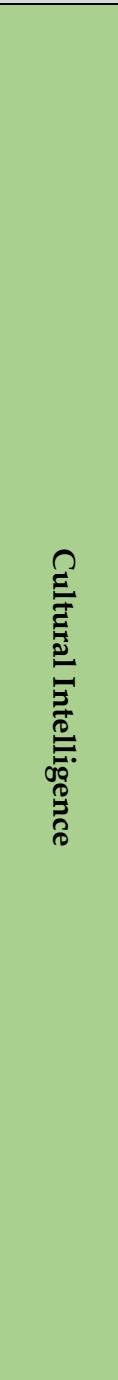 } \\
\hline 131 & & & & \\
\hline 132 & & & & \\
\hline 133 & & & & \\
\hline 134 & \multirow{9}{*}{$\begin{array}{l}\text { culture sensitivity } \\
\text { understanding diversity of culture } \\
\text { be sensitive to culture, local festivals, diversity } \\
\text { GVTs-understanding cultural nuances help } \\
\text { culture-be sympathetic } \\
\text { diff cultures have diff motivation factors } \\
\text { Understand diversity at deeper level to respect } \\
\text { other culture, style and ethics. } \\
\text { cultures - need to understand and adjust } \\
\text { cultural aspect important }\end{array}$} & & \multirow{19}{*}{$\begin{array}{l}\text { Culture } \\
\text { Sensitivity }\end{array}$} & \\
\hline 135 & & & & \\
\hline 136 & & & & \\
\hline 137 & & & & \\
\hline 138 & & & & \\
\hline 139 & & & & \\
\hline 140 & & & & \\
\hline 141 & & & & \\
\hline 142 & & & & \\
\hline 143 & \multirow{6}{*}{$\begin{array}{l}\text { language - some cultures are very aggressive, some } \\
\text { are comfortable } \\
\text { email etiquette is very important, interpretation of } \\
\text { email depends on mood of reader } \\
\text { communication details, expectations and outcomes } \\
\text { for all members across cultures } \\
\text { being careful with words while responding to } \\
\text { emails } \\
\text { culture, contact switching, speak English in different } \\
\text { way } \\
\text { training on cultural difference - avoid } \\
\text { misinterpretation of expectations }\end{array}$} & \multirow{6}{*}{$\begin{array}{l}\text { Etiquette, } \\
\text { Language, and } \\
\text { Preparedness } \\
\text { across Cultures }\end{array}$} & & \\
\hline 144 & & & & \\
\hline 145 & & & & \\
\hline 146 & & & & \\
\hline 147 & & & & \\
\hline 148 & & & & \\
\hline 149 & \multirow{4}{*}{$\begin{array}{l}\text { preparedness can reduce cultural difference } \\
\text { do proper homework } \\
\text { consciousness will bring in adaptability, culture } \\
\text { sensitivity and humility } \\
\text { understanding culture }\end{array}$} & \multirow{4}{*}{$\begin{array}{l}\text { Preparedness } \\
\text { about culture }\end{array}$} & & \\
\hline 150 & & & & \\
\hline 151 & & & & \\
\hline 152 & & & & \\
\hline
\end{tabular}

Copyright: (c) 2019 Shaik \& Makhecha. This is an open-access article distributed under the terms of the Creative Commons Attribution-NonCommercial 3.0 Australia License, which permits non-commercial use, distribution, and reproduction in any medium, provided the original author and AJIS are credited. 
Australasian Journal of Information Systems

2019, Vol 23, Research on the Role of Tech in Workforce Mgt
Shaik \& Makhecha

Employee Engagement in Virtual Teams

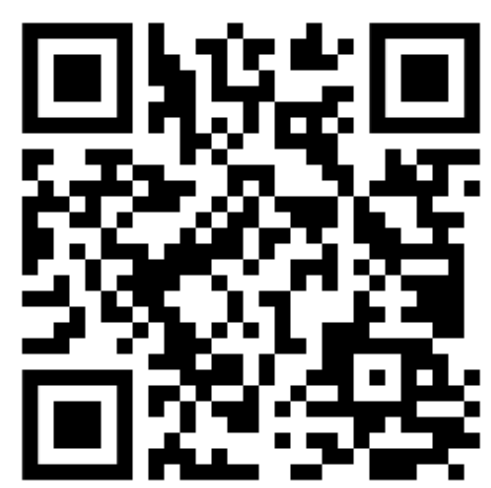

